Article

\title{
Corundum Anorthosites-Kyshtymites from the South Urals, Russia: A Combined Mineralogical, Geochemical, and U-Pb Zircon Geochronological Study
}

\author{
Maria I. Filina ${ }^{1, * \mathbb{C}}$, Elena S. Sorokina ${ }^{1,2} \mathbb{C}^{\mathbb{C}}$, Roman Botcharnikov ${ }^{2}$, Stefanos Karampelas ${ }^{3}$, \\ Mikhail A. Rassomakhin ${ }^{4,5}$, Natalia N. Kononkova ${ }^{1}$, Anatoly G. Nikolaev ${ }^{6}$, Jasper Berndt ${ }^{7}$ and \\ Wolfgang Hofmeister ${ }^{2}$ (I) \\ 1 Vernadsky Institute of Geochemistry and Analytical Chemistry Russian Academy of Sciences (GEOKHI \\ RAS), Kosygin str. 19, 119991 Moscow, Russia; elensorokina@mail.ru (E.S.S.); nnzond@geokhi.ru (N.N.K.) \\ 2 Institut für Geowissenschaften, Johannes Gutenberg Universität Mainz, J.-J.-Becher-Weg 21, 55128 Mainz, \\ Germany; rbotchar@uni-mainz.de (R.B.); hofmeister@uni-mainz.de (W.H.) \\ 3 Bahrain Institute for Pearls \& Gemstones (DANAT), WTC East Tower, P.O. Box 17236 Manama, Bahrain; \\ stefanos.karampelas@gmail.com \\ 4 Institute of Mineralogy SU FRC MiG UB RAS, 456317 Miass, Chelyabinsk Region, Russia; \\ miha_rassomahin@mail.ru \\ 5 Ilmen State Reserve SU FRC MiG UB RAS, 456317 Miass, Chelyabinsk Region, Russia \\ 6 Department of mineralogy and lithology, Institute of Geology and Petroleum Technologies, Kazan Federal \\ University, 420008 Kazan, Russia; anatolij-nikolaev@yandex.ru \\ 7 Institut für Mineralogie, Westfälische Wilhelms Universität Münster, Corrensstrasse 24, 48149 Münster, \\ Germany; jberndt@uni-muenster.de \\ * Correspondence: makimm@mail.ru; Tel.: +7(499)137-14-84
}

Received: 25 February 2019; Accepted: 11 April 2019; Published: 16 April 2019

check for updates

\begin{abstract}
Kyshtymites are the unique corundum-blue sapphire-bearing variety of anorthosites of debatable geological origin found in the Ilmenogorsky-Vishnevogorsky complex (IVC) in the South Urals, Russia. Their mineral association includes corundum-sapphire, plagioclase $\left(\mathrm{An}_{61-93}\right)$, muscovite, clinochlore, and clinozoisite. Zircon, churchite-( $(\mathrm{Y})$, monazite-(Ce), and apatite group minerals are found as accessory phases. Besides, churchite- $(Y)$ and zircon are also identified as syngenetic solid inclusions within the sapphires. In situ Laser Ablation Inductively Coupled Plasma Mass Spectrometry (LA-ICP-MS) U-Pb zircon geochronology showed the ages at about 290-330 Ma linked to the Hercynian orogeny in IVC. These ages are close to those of the syenitic and carbonatitic magmas of the IVC, pointing to their syngenetic origin, which is in agreement with the trace element geochemistry of the zircons demonstrating clear magmatic signature. However, the trace element composition of sapphires shows mostly metamorphic signature with metasomatic overprints in contrast to the geochemistry of zircons. The reason for this discrepancy can be the fact that the discrimination diagrams for sapphires are not as universal as assumed. Hence, they cannot provide an unambiguous determination of sapphire origin. If it is true and zircons can be used as traces of anorthosite genesis, then it can be suggested that kyshtymites are formed in a magmatic process at 440-420 Ma ago, most probably as plagioclase cumulates in a magma chamber. This cumulate rock was affected by a second magmatic event at 290-330 Ma as recorded in zircon and sapphire zoning. On the other hand, Ti-in-zircon thermometer indicates that processes operated at relatively lower temperature $\left(<900^{\circ} \mathrm{C}\right)$, which is not enough to re-melt the anorthosites. Hence, zircons in kyshtymites can be magmatic but inherited from another rock, which was re-worked during metamorphism. The most probable candidate for the anorthosite protolith is carbonatites assuming that metamorphic fluids could likely leave $\mathrm{Al}$ - and Si-rich residue, but removed $\mathrm{Ca}$ and $\mathrm{CO}_{2}$. Further, $\mathrm{Si}$ is consumed by the silicification of ultramafic host rocks. However, kyshtymites do not show clear evidence
\end{abstract}


of pronounced metasomatic zonation and evidence for large volume changes due to metamorphic alteration of carbonatites. Thus, the obtained data still do not allow for univocal reconstruction of the kyshtymite origin and further investigations are required.

Keywords: blue sapphire; anorthosites; kyshtymites; sapphire geochemistry; IlmenogorskyVishnevogorsky complex; in situ LA-ICP-MS U-Pb zircon dating

\section{Introduction}

Corundum $\alpha-\mathrm{Al}_{2} \mathrm{O}_{3}$ is the common mineral of many magmatic and metamorphic rocks. However, its blue gem-quality variety (i.e., sapphire) colored mainly by iron and titanium is rare and commonly found in secondary placers of debatable origin [1]. Recent studies of blue sapphires from different deposits worldwide demonstrate growing interest in their genesis due to findings of blue sapphires in situ within the primary rocks, for instance, those from alkali basaltic terrains [2-8].

Corundum in anorthosites is seldomly found worldwide and rarely of gem-quality, e.g., there is anorthosite occurrence with gem-quality pink corundum discovered in Fiskenaesset complex of W. Greenland. Pink corundum associated with coarse-grained, radial anthophyllite, green pargasite, green or red spinel, sapphirine, cordierite, and phlogopite [9]. Anorthosites with pink corundum are known from the Sittampundi Layered Complex, Tamil Nadu in India. These anorthosites belong to the rare group of metamorphosed Archean layered complexes, which are the part of oceanic crust formed in back-arc settings [10]. Anorthosites with colorless corundums were also found in Central Fiordland, New Zealand, where anorthositic complex is a part of the Tuyuan orogenic belt undergone a multiphase metamorphism of the amphibolite facies [11]. Another corundum anorthosite from the Chunky Gal Mountain (North Carolina, USA) [12] with pink-colored corundum is located in association with amphibolites and peridotites within alpine-type orogenic belt [13].

Corundum anorthosites (kyshtymites) are known for more than two centuries in South Urals of Russia; however, the genesis of these rocks remains enigmatic with the latest research results performed more than 50 year ago. For better understanding the origin of kyshtymites, their mineralogy, in situ LA-ICP-MS trace-element geochemistry and geochronology of zircon, and UV-Vis-NIR spectroscopy were studied by modern analytical techniques. The obtained data provide new insights into the origin of blue sapphires in anorthosites of Ilmenogorsky-Vishnevogorsky complex (IVC). Mineralogy and geochemistry of sapphires within kyshtymites were also compared to those found in other primary occurrences in IVC of South Urals (corundum-blue sapphire syenite pegmatites, and sapphire-bearing metasomatites within meta-ultramafic host rocks) and to those from secondary placer occurrences with similar geochemical and mineralogical features.

\section{Geological Setting}

The studied corundum deposit named "the 5th versta" was discovered by Karpinsky in 1883 [14]. Three kyshtymite veins were discovered during exploration of the deposit. Corundum was used mainly as an abrasive material, some of the crystals were gem-quality, however, these rough crystals did not exceed 1 carat. The exploration of the deposit was prosecuted until the 1930s and, currently, the occurrence is almost exhausted.

Blue sapphires in kyshtymites (the 5th versta deposit and the larger occurrence called Borzovsky deposit [15-17]) are located at the western flank of Vishnevogorsky nepheline syenite (miascite)carbonatite alkaline complex of the South Urals with unique REE-mineralization [18] (Figure 1). These two deposits are accompanied by other primary sapphire occurrences in syenite pegmatites (mines 298 and 349) [2] and sapphires in metasomatites within meta-ultramafic host rocks (mine 418) (Figure 1) [3]. 


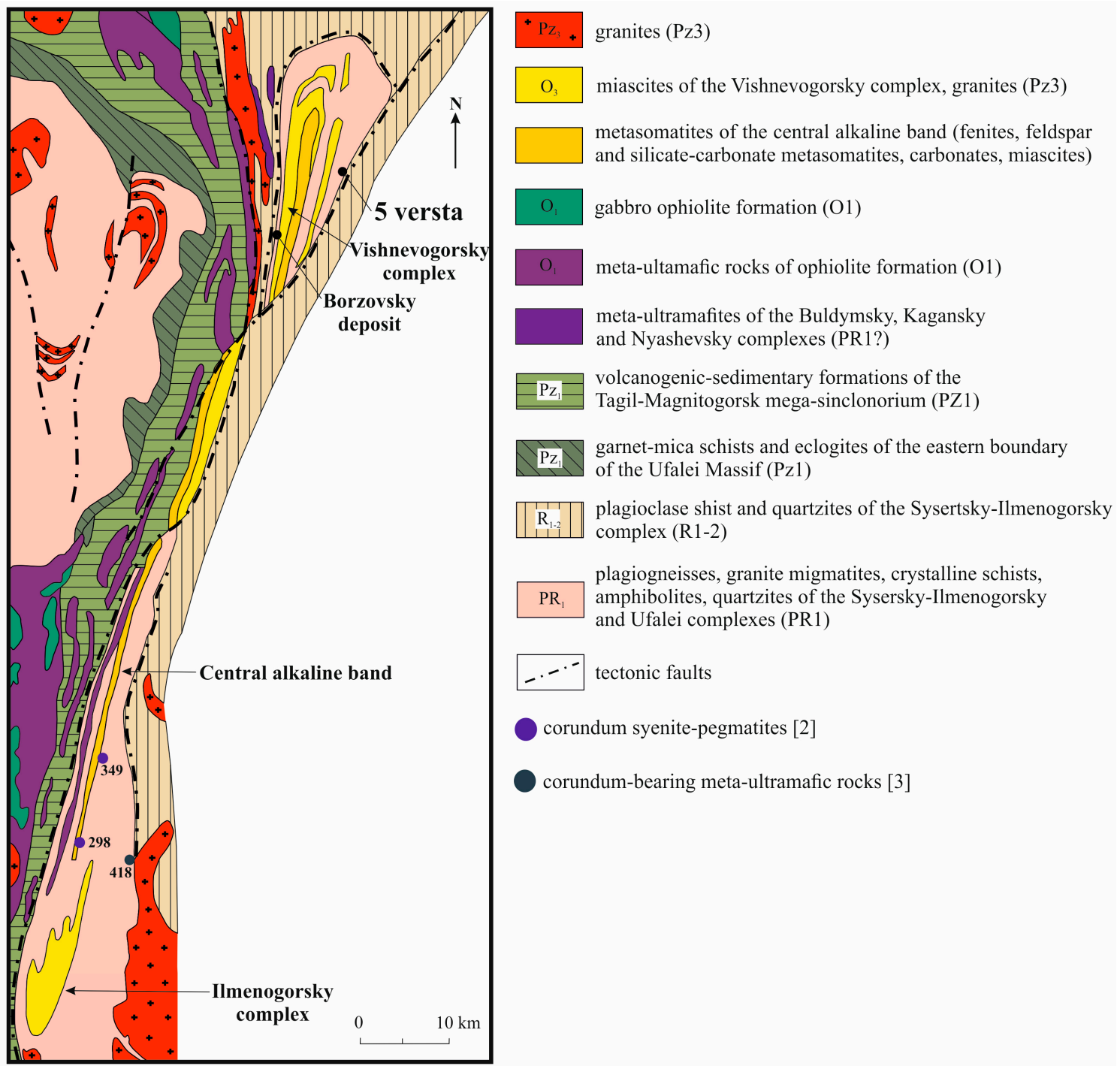

Figure 1. Geology of the Ilmenogorsky-Vishnevogorsky alkaline-carbonatite complex [18]. Coordinates of the 5 th versta deposit are $55^{\circ} 54^{\prime} 03^{\prime \prime} \mathrm{N}, 60^{\circ} 41^{\prime} 16^{\prime \prime} \mathrm{E}$.

The kyshtymites are found within the meta-ultramafic host rocks located among the quartzite shales of the meta-terrigenous Saitovsky series. Saitovsky series is one of the structural units within the Ilmenogorsky-Vishnevogorsky polymetamorphic zone, which is a deep fragment of the regional post-collisional shear [19]. The series with meta-ultramafites undergone the re-working during several thermal events (SHRIMP U-Pb zircon geochronology). The age of the mantle protolith was dated at $\sim 1.3 \mathrm{Ga}$ [20]. A stage of metamorphic evolution linked to the miascite intrusions was at about 450-420 Ma [21-23]. The stage of metamorphism and granite formation in the Sysertsky-Ilmenogorsky block linked to the Hercynian orogeny was at 360-320 Ma [24], whereas the ages of $\sim 330-270 \mathrm{Ma}$ corresponds to the collision processes [24].

At the beginning of the 20th century, the studied vein of kyshtymites of a lenticular body (Figure 2) was explored from the surface by quarry extended currently to the depth of about 3-4 m. The meta-ultramafic host rocks (initial orthopyroxenites) were composed mainly of enstatite, which undergone metasomatism (serpentinization). The reaction rim with a thickness of $10-25 \mathrm{~cm}$ consisting of chrysotile-asbestos was detected at the contact of the meta-ultramafic host rock with the kyshtymites [25]. 

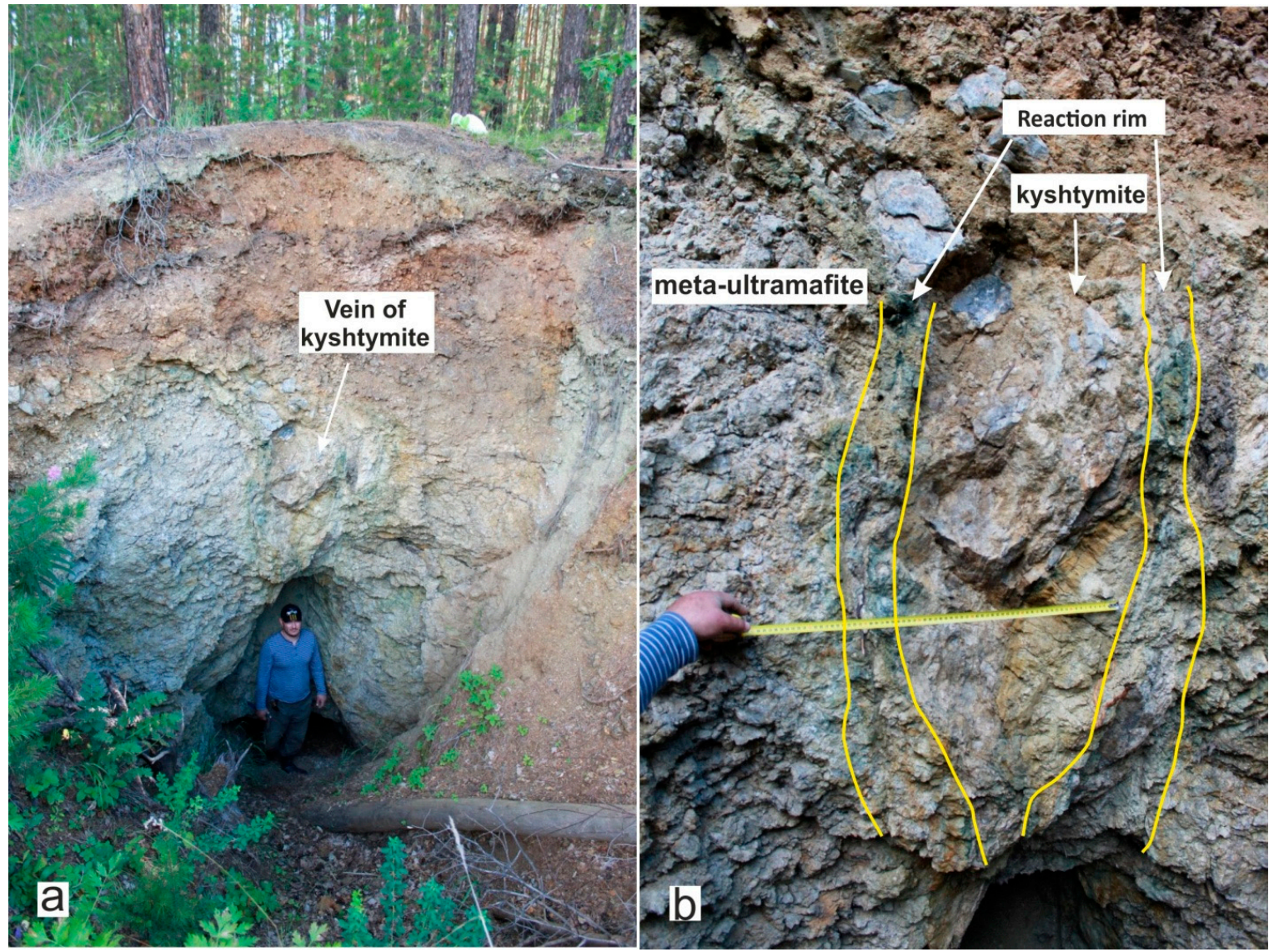

Figure 2. Vein of corundum-blue sapphire anorthosites-kyshtymites: (a) the kyshtymite outcrop, thickness is about $3 \mathrm{~m}$; and (b) A kyshtymite vein is at a contact with the meta-ultramafic host rock, their contact showed by a green-colored reaction rim consisting of chrysotile-asbestos.

Kyshtymites with meta-ultramafic host rocks are adjacent from the west by the miascites (nepheline syenites) of the Vishnevogorsky complex consisting of potassium feldspar (20-60 wt. \%), nepheline (20-30 wt. \%), lepidomelane (5-20\% wt. \%), amphibole (up to $20 \mathrm{wt} . \%$ ), and plagioclase (up to $20 \mathrm{wt}$ \%). Additionally, calcite (up to 3 wt. \%), cancrinite, and sodalite were identified in miascites [26].

\section{Materials and Methods}

Fourteen kyshtymite samples with blue corundum-sapphires, one sample from the reaction rim, and one sample of meta-ultramafic host rock were investigated in this study. The list of research methods is provided in Table S1. Minerals of kyshtymites, meta-ultramafic host rock, and the reaction rim between them were identified by the optical microscopy in the petrographic thin-sections. Some of the samples were studied by the Raman spectroscopy at the Renishaw Moscow using the Renishaw inVia Raman spectrometer coupled with $\mathrm{Ar}^{+}$green Stellar-REN Modu-Laser (Renishaw plc, Gloucestershire, UK) with $\lambda=514 \mathrm{~nm}$ and $50 \times$ magnification at room temperature. The laser power was $10 \mathrm{~mW}$ on the sample with a $60 \mathrm{~s}$ acquisition time (three cycles), at a resolution of about $1.5 \mathrm{~cm}^{-1}$. Rayleigh scattering was blocked using a holographic notch filter. Backscattered light was dispersed using a grating with 1800 grooves $/ \mathrm{mm}$. The spectrometer was calibrated at $520.7 \mathrm{~cm}^{-1}$ using Si as a reference.

The mineral chemistry was studied by the electron micro-probe analyses (EMPA) using Cameca SX 100 electron microprobe (CAMECA, Gennevilliers, France) in the wavelength-dispersive detection mode (WDS) at GEOKHI RAS, Moscow. The accelerating voltage was $15 \mathrm{kV}$, current was $30 \mathrm{nA}$, and beam size was from 3 to $5 \mu \mathrm{m}$. Both natural and synthetic reference materials were used for the instrument control: andradite for $\mathrm{Si}$, jadeite for $\mathrm{Na}$, orthoclase for $\mathrm{K}$ and $\mathrm{Al}$, augite for $\mathrm{Ca}$ and $\mathrm{Fe}$, olivine for $\mathrm{Mg}$, rhodonite for $\mathrm{Mn}, \mathrm{TiO}_{2}$ for $\mathrm{Ti}$, vanadinite for $\mathrm{V}, \mathrm{Cr}_{2} \mathrm{O}_{3}$ for $\mathrm{Cr}$, apatite for $\mathrm{P}$, galena 
for $\mathrm{Pb}, \mathrm{Rb}_{2} \mathrm{Nb}_{4} \mathrm{O}_{11}$ for $\mathrm{Nb}$, xenotime-( $\left.\mathrm{Y}\right)$ for $\mathrm{Y}$, metallic Gd for $\mathrm{Gd}, \mathrm{Pr}_{3} \mathrm{PO}_{4}$ for $\mathrm{Pr}, \mathrm{Sm}_{3} \mathrm{PO}_{4}$ for $\mathrm{Sm}$, $\mathrm{La}_{3} \mathrm{PO}_{4}$ for $\mathrm{La}$, and homogeneous glasses for $\mathrm{Zr}, \mathrm{Ta}$, Th, and $\mathrm{U}$. The detection limits for almost all elements were less than $0.01 \mathrm{wt}$. \%, the lower limits of the determined values were less about $0.03 \mathrm{wt} . \%$. Correction coefficients are determined by PAP correlation (atomic number, fluorescence, and absorption correction).

Trace element composition of three representative sapphire crystals from samples K-8 and K-12 was determined using Laser Ablation-Inductively Coupled Plasma-Mass Spectrometry (LA-ICP-MS) at the Institute of Geology of Ore Deposits, Petrography, and Mineralogy RAS (IGEM RAS), Moscow. The analyses were conducted using New Wave Research UP-213 Nd:YAG laser (New Wave Research, Inc., Fremont, CA, USA) combined with the XSERIES 2 ICP-Mass Spectrometer (Thermo Scientific, Waltham, MA, USA). Trace-element concentrations were determined by the monitoring of ${ }^{6} \mathrm{Li},{ }^{9} \mathrm{Be}$, ${ }^{24} \mathrm{Mg},{ }^{27} \mathrm{Al},{ }^{44} \mathrm{Ca},{ }^{47} \mathrm{Ti},{ }^{51} \mathrm{~V},{ }^{53} \mathrm{Cr},{ }^{57} \mathrm{Fe},{ }^{71} \mathrm{Ga}$, and ${ }^{91} \mathrm{Zr}$ and ablating a material with a spot size of $60 \mu \mathrm{m}$ at a repetition rate of $10 \mathrm{~Hz}$, and an energy density of about $14-15 \mathrm{~J} / \mathrm{cm}^{2}$. Warm up/background time was $15 \mathrm{~s}$, dwell time was $40 \mathrm{~s}$, and wash out time was $20 \mathrm{~s}$. The NIST SRM 610 and NIST SRM 612 glasses were used as reference materials and the BHVO-2G glass as a quality control material (QCM). The time-resolved signal was processed in Igor (IOLITE) commercial software using ${ }^{27} \mathrm{Al}$ as the internal standard applying the theoretical value of $52.93 \mathrm{wt}$. \% of $\mathrm{Al}$ in pure crystalline $\alpha-\mathrm{Al}_{2} \mathrm{O}_{3}$ for analyzing the corundum unknowns. The measured concentrations of reference material and QCM agree for all elements within $10 \%$ and $15 \%$, respectively, of preferred values by Jochum et al. 2011 [27]. This larger discrepancy between measured and preferred values can be attributed to isobaric interferences that cannot be resolved with the instrumentation used [28].

UV-Vis-NIR (Ultraviolet-Visible-Near Infrared) absorption spectroscopy was acquired at Kazan Federal University on one sapphire (sample 12-K). Spectra were recorded at a room temperature using SHIMADZU UV-3600 spectrometer (Shimadzu Corp, Kyoto, Japan) with 2 light sources (one for UV and one for Vis-NIR) and 2 detectors (FEU R928 for UV-Vis and InGaAs for NIR) from 185 to $3300 \mathrm{~nm}$ range with a data interval and spectra bandwidth of $1 \mathrm{~nm}$ and a scan rate of $300 \mathrm{~nm} / \mathrm{min}$.

Chemical composition of six selected kyshtymite rock samples macroscopically representing different textures and containing from 30 to $50 \mathrm{wt}$. \% of sapphires, one sample of meta-ultramafic host rocks, and one sample of reaction rim were used for whole-rock major element analyses at GEOKHI RAS, Moscow using Energy Dispersive X-ray Fluorescence spectrometer (EDXRF) AXIOS Advanced (PANalytical B.V., Almelo, The Netherlands). The equipment provides the determination of quantitative concentrations of elements from oxygen to uranium from about $10^{-4}$ to $100 \mathrm{wt}$. $\%$.

Three selected kyshtymite rock samples containing from 50 to $70 \mathrm{wt} . \%$ of sapphires with gem-quality zones in crystals, one sample of meta-ultramafic host rocks, and one sample of the reaction rim between kyshtymites and host rocks previously analyzed by EDXRF were used for the whole-rock trace-element analyses at the Institute of Oceanology RAS, Moscow. Inductively Coupled Plasma-Mass Spectrometer (ICP-MS) Agilent 7500 (Santa Clara, Ca, USA) was applied to determine the contents of REE and trace-elements. Calibration of the sensitivity over the entire mass scale was carried out using 68-element solutions references (ICP-MS-68A, HPS, solutions A and B). The STM-2 standard was used as a quality control material. Indium was added to all sample solutions in the concentration of $10 \mathrm{ng} / \mathrm{g}$ to control signal stability. The detection limits of the elements were $0.1 \mathrm{ng} / \mathrm{g}$ for the heavy and medium elements, and $1 \mathrm{ng} / \mathrm{g}$ for the light elements. Analytical uncertainties were less than $1-3 \%$.

Trace-element composition and U-Pb isotopic analysis of 6 zircon grains identified in the thin-section of samples 8-K were analyzed using Element2 ICP-Mass Spectrometer (ThermoFisher Scientific, Waltham, MA, USA) coupled with an Analyte G2 (Photon Machines Inc, Redmond, WA, USA) laser at the Westfälische Wilhelms Universität Münster. Before the analysis, the backscattered electron (BSE) and cathodoluminescence (CL) images, as well as maps in average weighted atomic numbers were taken at GEOKHI RAS, Moscow using the same equipment as for the EMPA WDS to identify the internal structures within the zircon grains. During the LA-ICP-MS measurements, gas flow rates were about $1.1 \mathrm{~L} / \mathrm{min}$ for $\mathrm{He}, 0.9 \mathrm{~L} / \mathrm{min}$ and $1.1 \mathrm{~L} / \mathrm{min}$ for the Ar-auxiliary and sample gas, 
respectively. Cooling gas flow rate was set to $16 \mathrm{~L} / \mathrm{min}$. Trace-elements concentrations were determined by measuring of ${ }^{29} \mathrm{Si},{ }^{43} \mathrm{Ca},{ }^{49} \mathrm{Ti},{ }^{51} \mathrm{~V},{ }^{53} \mathrm{Cr}$, and $\mathrm{REE}$ with a spot size of $20 \mu \mathrm{m}$ at a repetition rate of $10 \mathrm{~Hz}$, and an energy density of about $\sim 3-4 \mathrm{~J} / \mathrm{cm}^{2}$. Background time was $15 \mathrm{~s}$, dwell time was $40 \mathrm{~s}$, and wash out time was $20 \mathrm{~s}$. NIST SRM 612 was used as the reference materials, and 91,500 zircon and BIR-1G glass as unknowns for quality control (QCM). The time-resolved signal was processed in GLITTER commercial software using $\mathrm{Zr}$ as the internal standard applying the stoichiometric value of $\mathrm{Zr}$ in pure crystalline $\mathrm{ZrSiO}_{4}$ for analyzing the zircon unknowns. The measured concentrations of reference material and QCM agree for all elements within 10\% and 15\%, respectively, of preferred values by [29]. For U-Pb zircon dating ${ }^{204} \mathrm{~Pb},{ }^{206} \mathrm{~Pb},{ }^{207} \mathrm{~Pb}$, and ${ }^{238} \mathrm{U}$ were measured along, with ${ }^{202} \mathrm{Hg}$ to correct the interference of ${ }^{204} \mathrm{Hg}$ on ${ }^{204} \mathrm{~Pb}$, which is important to apply, if necessary, for a common $\mathrm{Pb}$ correction. Repetition rate was $10 \mathrm{~Hz}$ using an energy of $\sim 3 \mathrm{~J} / \mathrm{cm}^{2}$ and a spot size of $25 \mu \mathrm{m}$. Ten unknowns were bracketed with three calibration standards GJ1 [29] to correct for instrumental mass bias. The data reduction was performed using in-house Excel spreadsheet [30]. Along with the unknowns, 91,500 reference zircon [31] was measured to monitor accuracy and precision of the analysis. Long term reproducibility of the reference zircon standard 91,500 [31] yielded a Concordia age of 1074.8 $\pm 8.8 \mathrm{Ma}$, which is indistinguishable to the age of $1065.4 \pm 0.3 \mathrm{Ma}$ for the 91,500 reference zircon determined by TIMS [31]. The Concordia diagrams and age calculations were made using Isoplot v. 4.13 (Ludwig, 2009) [32]. Weighted mean age calculations are given at 95\% confidence level.

\section{Results}

\subsection{Petrology and Mineralogy of Kyshtymites}

Mineral composition and chemistry are shown in Tables S2-S4. Kyshtymite consists mainly of idiomorphic blue-colored transparent to translucent corundums-sapphires (up $50 \mathrm{wt}$. \%) and plagioclase with composition varying from labradorite to anorthite $\mathrm{An}_{61-93}$ (30-50 wt. \%) (Table S3 and Figure 3).

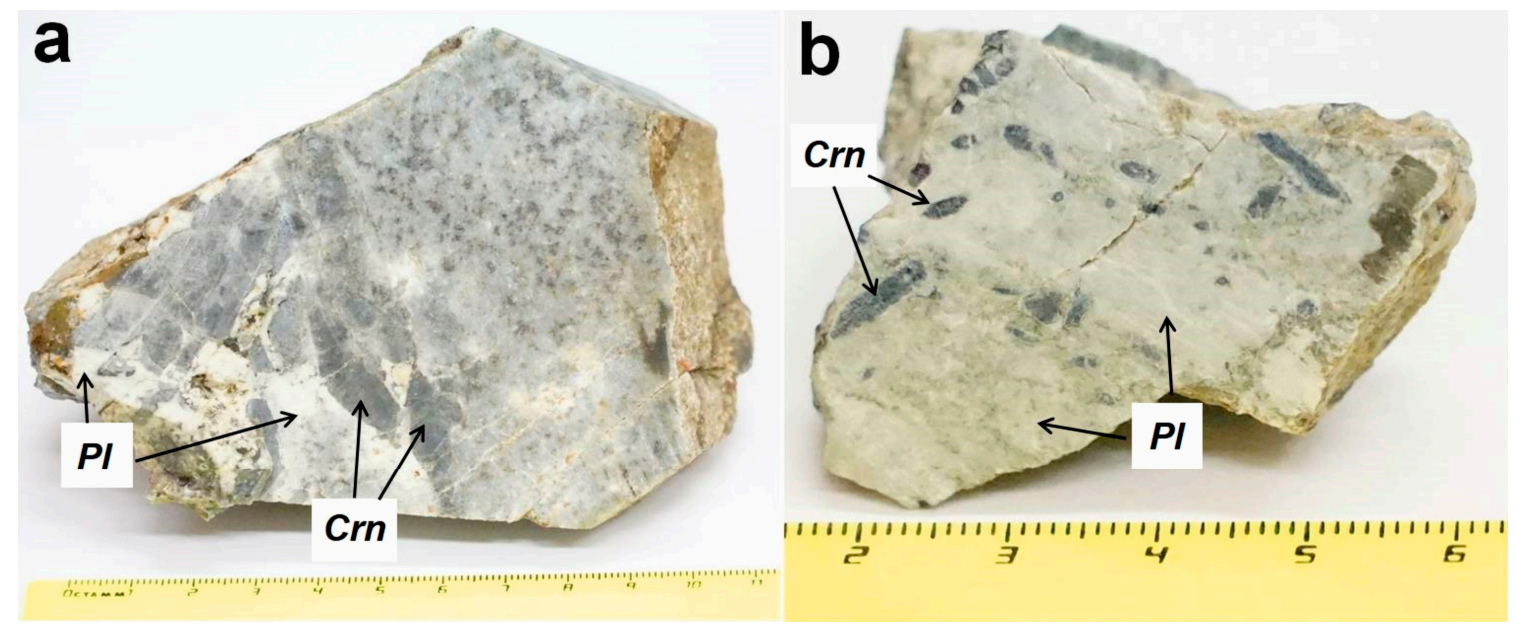

Figure 3. Photography of the samples used in this study with dipyramidal-prismatic corundumsapphires (Crn) crystals elongated along the $c$ axis and fine-grained plagioclase (Pl): (a) sample 2-K; and (b) sample 7-K.

The rock has a porphyritic structure, where large corundum-sapphire crystals are located among the fine-grained plagioclase, muscovite, clinozoisite, and clinochlore (Figure 4). Other rock-forming minerals-muscovite, clinochlore, and clinozoisite-occupy up to $10 \mathrm{wt}$. \%. Accessory minerals were detected as zircon, churchite-(Y), apatite, and monazite-(Ce) (Figure 5). 
Table 1. Rim-to-rim LA-ICP-MS profiles of studied corundum-blue sapphire from anorthosites- kyshtymites (in $\mu \mathrm{g} / \mathrm{g}$ ).

\begin{tabular}{|c|c|c|c|c|c|c|c|c|c|c|c|c|c|c|}
\hline \multicolumn{2}{|c|}{ Sample/No. of Spot } & \multirow{2}{*}{$\begin{array}{c}\text { Color } \\
\mathrm{Wt}\end{array}$} & \multirow{2}{*}{$\begin{array}{c}\mathbf{L i} \\
32.45\end{array}$} & \multirow{2}{*}{$\begin{array}{c}\mathbf{B e} \\
1.85\end{array}$} & \multirow{2}{*}{$\begin{array}{c}\text { Mg } \\
199.85\end{array}$} & \multirow{2}{*}{$\begin{array}{c}\mathbf{T i} \\
972.77\end{array}$} & \multirow{2}{*}{$\frac{\mathrm{V}}{5.59}$} & \multirow{2}{*}{$\frac{\mathrm{Cr}}{3.18}$} & \multirow{2}{*}{$\frac{\mathbf{F e}^{*}}{1166.20}$} & \multirow{2}{*}{$\begin{array}{c}\text { Ga } \\
36.40\end{array}$} & \multirow{2}{*}{$\begin{array}{c}\mathrm{Ga} / \mathrm{Mg} \\
0.18\end{array}$} & \multirow{2}{*}{$\begin{array}{c}\mathbf{F e} / \mathrm{Ti} \\
1.20\end{array}$} & \multirow{2}{*}{$\begin{array}{c}\mathrm{Cr} / \mathrm{Ga} \\
0.09\end{array}$} & \multirow{2}{*}{$\begin{array}{c}\mathrm{Fe} / \mathrm{Mg} \\
5.84\end{array}$} \\
\hline $\mathrm{K}-8-1$ & 1 & & & & & & & & & & & & & \\
\hline & 2 & $\mathrm{Bl}$ & 8.34 & 1.67 & 183.70 & 700.93 & 5.96 & 12.34 & 1477.19 & 38.57 & 0.21 & 2.11 & 0.32 & 8.04 \\
\hline & 3 & $\mathrm{Bl}$ & bdl & bdl & 334.58 & 782.98 & 6.49 & 2.59 & 2099.17 & 36.90 & 0.11 & 2.68 & 0.07 & 6.27 \\
\hline & 5 & Wt & bdl & 2.20 & 69.22 & 231.35 & 7.54 & 2.59 & 1399.44 & 33.72 & 0.49 & 6.05 & 0.08 & 20.22 \\
\hline & 6 & $\mathrm{Wt}$ & bdl & 3.12 & 67.05 & 115.41 & 8.52 & 1.61 & 1710.43 & 33.38 & 0.50 & 14.82 & 0.05 & 25.51 \\
\hline & 7 & $\mathrm{Bl}$ & bdl & 2.51 & 66.78 & 101.64 & 9.08 & 2.44 & 2332.41 & 33.03 & 0.49 & 22.95 & 0.07 & 34.92 \\
\hline & 8 & $\mathrm{Bl}$ & bdl & bdl & 291.17 & 458.20 & 5.35 & 3.86 & 1865.92 & 32.00 & 0.11 & 4.07 & 0.12 & 6.41 \\
\hline & 10 & $\mathrm{Wt}$ & bdl & bdl & 741.16 & 585.52 & 4.74 & 6.51 & 855.22 & 30.76 & 0.04 & 1.46 & 0.21 & 1.15 \\
\hline \multirow[t]{9}{*}{$\mathrm{K}-8-2$} & 1 & $\mathrm{Wt}$ & bdl & bdl & 131.29 & 986.27 & 5.53 & 6.04 & 1788.18 & 32.77 & 0.25 & 1.81 & 0.18 & 13.62 \\
\hline & 2 & $\mathrm{Bl}$ & bdl & bdl & 59.29 & 782.19 & 6.27 & 1.89 & 2021.42 & 36.16 & 0.61 & 2.58 & 0.05 & 34.09 \\
\hline & 3 & $\mathrm{Bl}$ & bdl & bdl & 46.67 & 706.48 & 6.38 & 1.60 & 2021.42 & 37.30 & 0.80 & 2.86 & 0.04 & 43.32 \\
\hline & 4 & $\mathrm{Bl}$ & bdl & bdl & 296.46 & 559.58 & 6.17 & 2.40 & 1865.92 & 37.19 & 0.13 & 3.33 & 0.06 & 6.29 \\
\hline & 5 & Wt & bdl & 3.47 & 127.59 & 164.38 & 8.63 & 2.52 & 1166.20 & 34.76 & 0.27 & 7.09 & 0.07 & 9.14 \\
\hline & 6 & $\mathrm{Wt}$ & bdl & 2.67 & 94.50 & 122.82 & 8.55 & 2.90 & 1166.20 & 34.46 & 0.36 & 9.50 & 0.08 & 12.34 \\
\hline & 7 & $\mathrm{Bl}$ & bdl & 2.33 & 92.62 & 133.67 & 8.60 & 1.86 & 1943.67 & 35.50 & 0.38 & 14.54 & 0.05 & 20.99 \\
\hline & 8 & $\mathrm{Bl}$ & bdl & bdl & 77.21 & 583.13 & 6.59 & 0.92 & 2410.15 & 39.81 & 0.52 & 4.13 & 0.02 & 31.21 \\
\hline & 10 & $\mathrm{Wt}$ & bdl & bdl & 91.85 & 711.78 & 5.17 & 0.93 & 1399.44 & 36.40 & 0.40 & 1.97 & 0.03 & 15.24 \\
\hline \multirow[t]{10}{*}{$\mathrm{K}-12-1$} & 1 & $\mathrm{Bl}$ & bdl & bdl & 164.38 & 939.95 & 3.97 & bdl & 1010.71 & 42.99 & 0.26 & 1.08 & - & 6.15 \\
\hline & 2 & $\mathrm{Wt}$ & bdl & 2.81 & 167.82 & 294.08 & 6.70 & bdl & 621.97 & 56.25 & 0.34 & 2.11 & - & 3.71 \\
\hline & 3 & Wt & bdl & 1.96 & 188.47 & 210.70 & 6.22 & bdl & 1321.70 & 61.33 & 0.33 & 6.27 & - & 7.01 \\
\hline & 4 & $\mathrm{Wt}$ & bdl & 3.60 & 147.68 & 216.79 & 6.49 & bdl & 4198.33 & 57.49 & 0.39 & 19.37 & - & 28.43 \\
\hline & 5 & $\mathrm{Wt}$ & bdl & 3.81 & 94.97 & 125.20 & 6.11 & bdl & 855.22 & 48.65 & 0.51 & 6.83 & - & 9.00 \\
\hline & 6 & Wt & bdl & bdl & 222.08 & 205.14 & 3.71 & bdl & 1554.94 & 50.95 & 0.23 & 7.58 & - & 7.00 \\
\hline & 7 & $\mathrm{Wt}$ & bdl & bdl & 127.77 & 156.44 & 6.14 & bdl & 1321.70 & 46.38 & 0.36 & 8.45 & - & 10.34 \\
\hline & 8 & $\mathrm{Bl}$ & bdl & 1.85 & 157.23 & 374.82 & 8.07 & bdl & 5209.04 & 52.41 & 0.33 & 13.90 & - & 33.13 \\
\hline & 9 & $\mathrm{Bl}$ & bdl & $\mathrm{bdl}$ & 190.32 & 524.11 & 8.71 & 0.03 & 3265.37 & 54.58 & 0.29 & 6.23 & - & 17.16 \\
\hline & 10 & $\mathrm{Bl}$ & bdl & bdl & 237.44 & 555.61 & 7.91 & 0.35 & 3109.87 & 50.90 & 0.21 & 5.60 & 0.01 & 13.10 \\
\hline
\end{tabular}

$\mathrm{Wt}, \mathrm{Bl}$, white and blue colors of sapphire. * Calculated fromWDS EMPA; bdl, below the detection limit. 


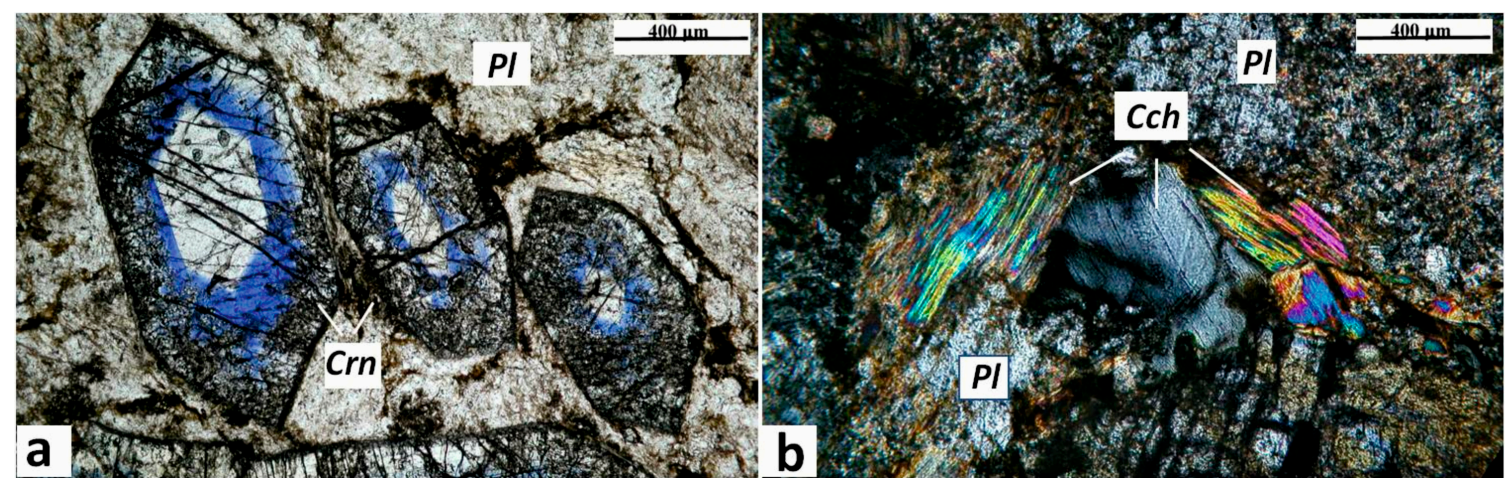

Figure 4. Photomicrographs of corundum-blue sapphire anorthosite-kyshtymite samples 8-K: (a) idiomorphic crystals of corundum-sapphire (Crn) with oscillatory white-blue zonation within the matrix of fine-grained plagioclase $(\mathrm{Pl})$, parallel polarized light. The dotted arrows show the profiles measured by LA-ICP-MS (cf. Table 1). (b) Xenomorphic crystals of clinochlore (Cch) associated with plagioclase, crossed polarized light.

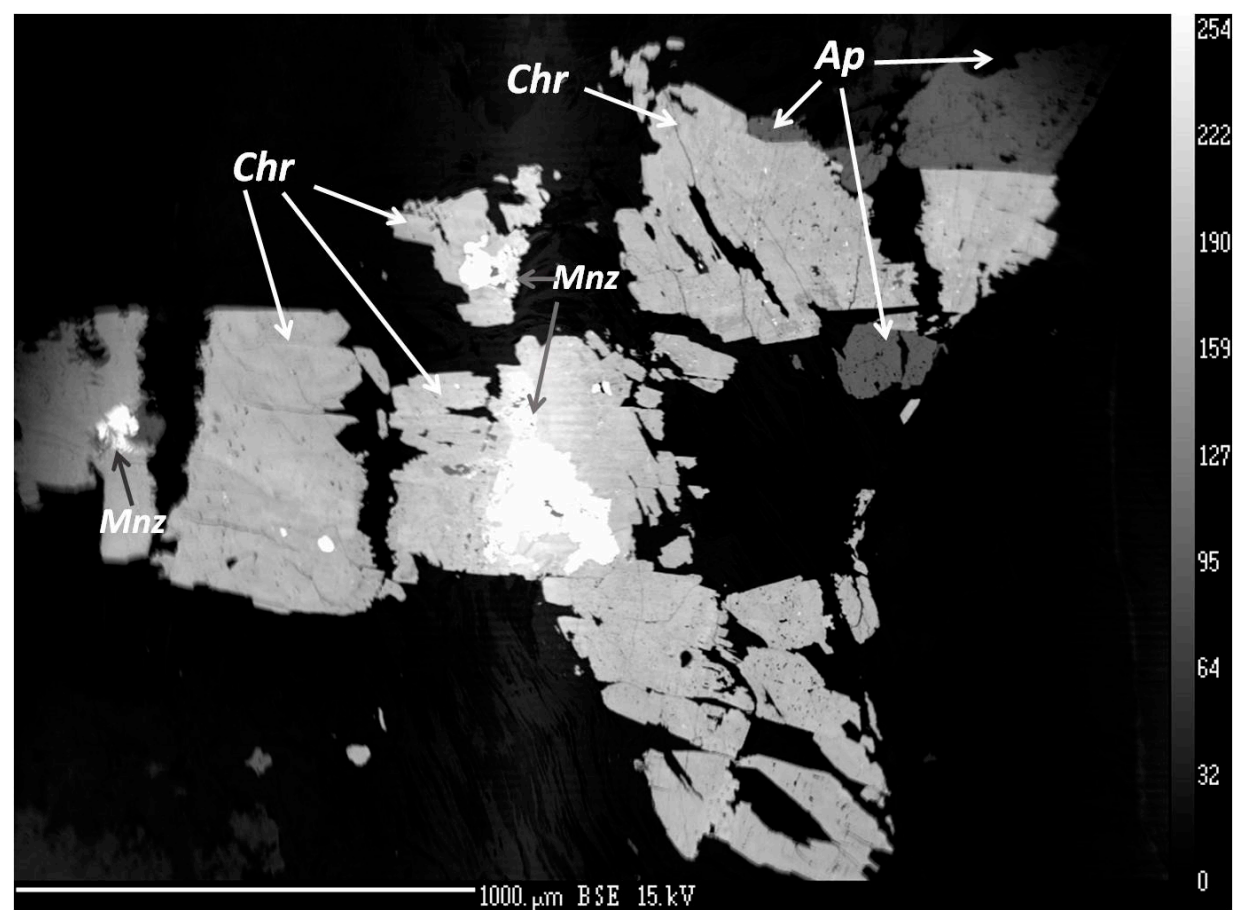

Figure 5. BSE image of churchite-(Y) (Chr), monazite-(Ce) (Mnz), and apatite group minerals (Ap) embedded in the plagioclase-muscovite-clinochlore matrix.

Muscovite occurs as plates of $0.1-0.2 \mathrm{~mm}$ in size common around plagioclase grains. The mineral is detected in association with clinochlore and clinozoisite, both epigenetic by nature. High $\mathrm{MgO}$ contents in muscovite (up to $1.71 \mathrm{wt}$. \%) and $\mathrm{K}_{2} \mathrm{O}$ in clinochlore (up to $7.11 \mathrm{wt}$. \%) are associated with the replacement of muscovite by a clinochlore. Clinozoisite forms small rounded grains up to $0.1 \mathrm{~mm}$ in size replacing plagioclase. Clinozoisite contains up to $\mathrm{FeO}_{\mathrm{tot}}$ of $2.07 \mathrm{wt}$. \%.

Churchite-(Y), forms small syngenetic xenomorphic crystals of 30-70 $\mu \mathrm{m}$ in size commonly found as solid micro-inclusions within corundum-sapphire (Figure 5). Churchite-(Y) is also found in intergrowths with the monazite-(Ce) and likely apatite group minerals (Table S3). Zircon forms syngenetic and epigenetic prismatic or dipyramidal crystals with a size up to 40-100 $\mu \mathrm{m}$, and contains up to 2.45 wt. \% $\mathrm{HfO}_{2}$ (Table S4). 


\subsection{Mineralogy, Geochemistry, Solid Inclusions, and UV-Vis-NIR-Spectroscopy of Corundum-Sapphire}

Colorless to blue-colored translucent to transparent corundum-sapphires with the fractures passing through the entire crystals were found in kyshtymites. All sapphires show oscillatory zonation in the elongated dipyramidal-prismatic crystal sized up to $4 \mathrm{~cm}$ in length (Figure $3 \mathrm{~b}$ ). The most developed crystal faces are hexagonal prism (1120), pinacoid (0001), and hexagonal dipyramid (22 $\overline{4} 3$ ) (Figure 4a).

Sapphires from kyshtymites are almost inclusion-free except occasional finding of churchite-(Y) and zircon solid inclusions. Churchite-( $(\mathrm{Y})$ was found to be syngenetic with sapphires (Figure 5). The mineral contains traces of $\mathrm{Gd}_{2} \mathrm{O}_{3}$ (1.8-2.19 wt. \%), $\mathrm{Pr}_{2} \mathrm{O}_{3}\left(0.10-0.17\right.$ wt. \%), $\mathrm{La}_{2} \mathrm{O}_{3}(0.09-0.12$ wt. \%), $\mathrm{Sm}_{2} \mathrm{O}_{3}\left(0.91-1.05\right.$ wt. \%), $\mathrm{U}_{2} \mathrm{O}_{3}\left(1.77-2.14\right.$ wt. \%), and $\mathrm{ThO}_{2}(0.55-72$ wt. \%). Inclusion of churchite-(Y) in sapphire has not been previously described. Therefore, it is likely the first identification and chemical analysis of churchite-(Y) solid inclusions within sapphires to the best of our knowledge.

Zircon solid inclusions in corundum-sapphire showed concentration of $\mathrm{HfO}_{2}$ from 0.72 to 3.00 wt. \% (one measurement showed 5.38 wt. \%; see Table S5), which is almost the same as in zircon found in mineral association of kyshtymites (0.97-2.45 wt. \%). Besides, the epigenetic zircon, muscovite, and clinochlore filling the sapphire fractures were also detected.

The UV-Vis-NIR spectra of the studied sapphires are comparable to those observed on sapphires of metamorphic or metasomatic origin [33] and of the other two occurrences in the region linked with syenitic pegmatite [2] and metasomatites within meta-ultramafic host rocks [3].

Corundum-sapphire trace element measurements by LA-ICP-MS are shown in Table 1. The Fe content in blue colored zones varies from 1010 to $5209 \mu \mathrm{g} / \mathrm{g}$. The concentration of $\mathrm{Mg}(47-335 \mu \mathrm{g} / \mathrm{g})$ and $\mathrm{Ti}(101-940 \mu \mathrm{g} / \mathrm{g})$ in sapphire from kyshtymites are higher than that in blue sapphires from syenite pegmatites (mines 298 and 349) [2,34] and those in sapphires from metasomatites in meta-ultramafic host rocks (mine 418) [3] (Table S6), both located in Ilmen Mountains (see Figure 1). The Ga content remains low (30-61 $\mu \mathrm{g} / \mathrm{g}$ ) for all studied samples as in the case of sapphires in meta-ultramafites (mine 418), however, lower than in those of syenite pegmatites (Table S6). Cr is from b.d.l. to $12 \mu \mathrm{g} / \mathrm{g}$ and $\mathrm{V}$ from 4 to $9 \mu \mathrm{g} / \mathrm{g}$. Detected Li and Be concentrations in the measured spots are presumably due to micro-inclusions within sapphires.

The $10,000 \mathrm{Ga} / \mathrm{Al}$ ratio is above $0.60-0.80, \mathrm{Ga} / \mathrm{Mg}$ ratio is $0.11-0.80, \mathrm{Fe} / \mathrm{Mg}$ is $6.15-43.32, \mathrm{Cr} / \mathrm{Ga}$ is $0.01-0.32$, and $\mathrm{Fe} / \mathrm{Ti}$ is 1.08-22.95. These ratios are common for metamorphic sapphires [35,36]. On the Fe versus $\mathrm{Ga} / \mathrm{Mg}$ diagram, studied sapphires with blue color fall in the field of metamorphic sapphire, similar (but not overlapping) to those of meta-ultramafic host rocks of Ilmen Mountains. The results are partially overlapping with those of magmatic sapphires in Yogo Gulch in USA, Gortva in Slovakia, Baw Mar in Myanmar (filled symbols in Figure 6), metamorphic sapphires from Ratnapura in Sri-Lanka, and metasomatic sapphires from Kashmir in India (dotted lines in Figure 6).

On the Fe-Mg*100- $\mathrm{Ti}^{*} 10$ ternary plot (Figure 7 ), the studied sapphires from kyshtymites also fall in the field of "metamorphic" sapphires overlapping those within Ilmen meta-ultramafic host rocks (mine 418). Meanwhile, blue sapphires from anorthosites-kyshtymites overlap most of the other known metamorphic (Ratnapura in Sri-Lanka-purple dotted lines in Figure 7), metasomatic (Kashmir in India-pink dotted lines in Figure 7), magmatic (Mogok in Myanmar, Yogo in USA, and Gortva, Slovakia-filled symbols in Figure 7), and placer sapphire occurrences (Balangoda in Sri Lanka, Pailin in Cambodia, and Ilakaka in Madagascar, and Montana in USA).

The sapphires from kyshtymites are also plotted to the "metamorphic" field on Fe/Mg vs. Ga/Mg diagram by Peucat et al. (2007) and Sutherland et al. (2009) [35,36] (Figure 8). 


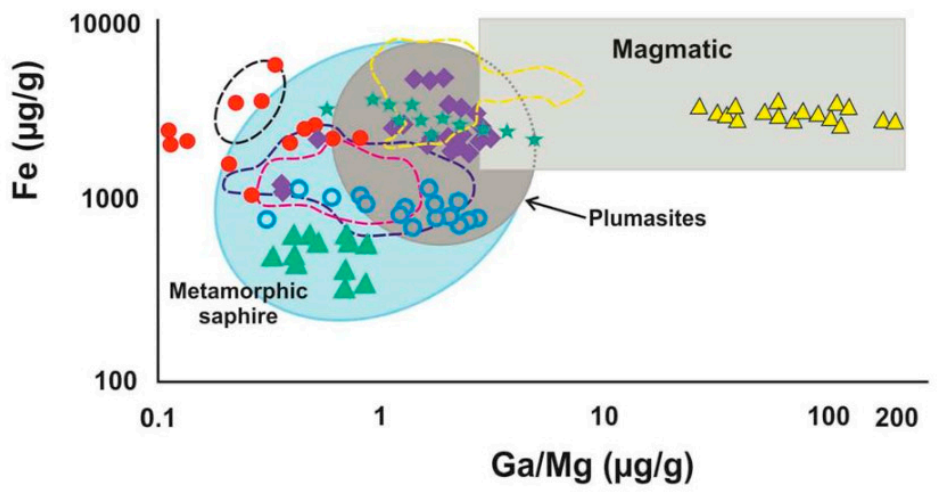

- Sapphires within kyshtymites

$\triangle$ IImen syenite pegmatite

O IImen within meta-ultramafic host rock

$\Delta$ Pailin (Cambodia)

- Baw Mar Mine in Mogok (Myanmar)

$\star$ Gortva (Slovakia)

-.- Alluvial sapphires in Montana (USA)

--- Kashmir (India)

--- Ratnapura Balangoda (Sri Lanka)

--- Yogo (USA)

Figure 6. A Fe versus $\mathrm{Ga} / \mathrm{Mg}$ diagram showing the boundaries for magmatic and metamorphic sapphires, modified after Peucat et al. (2007) [35] and Zwaan et al. (2015) [37] with blue sapphires within kyshtymites, Ilmen sapphires within syenite pegmatites [2], Ilmen sapphires within meta-ultramafic host rocks [3], and sapphire deposits from other regions after [35]: Ratnapura and Balangoda (Sri lanka), Kasmir (India), Yogo Gulch (USA), and Baw Mar Mine in Mogok. The plot of alluvial sapphires from Montana (USA) is after Zwaan et al. (2015) [37]; data on sapphires from the Hajacka, Gortva (Slovakia) are after Uher et al. (2012) [38].

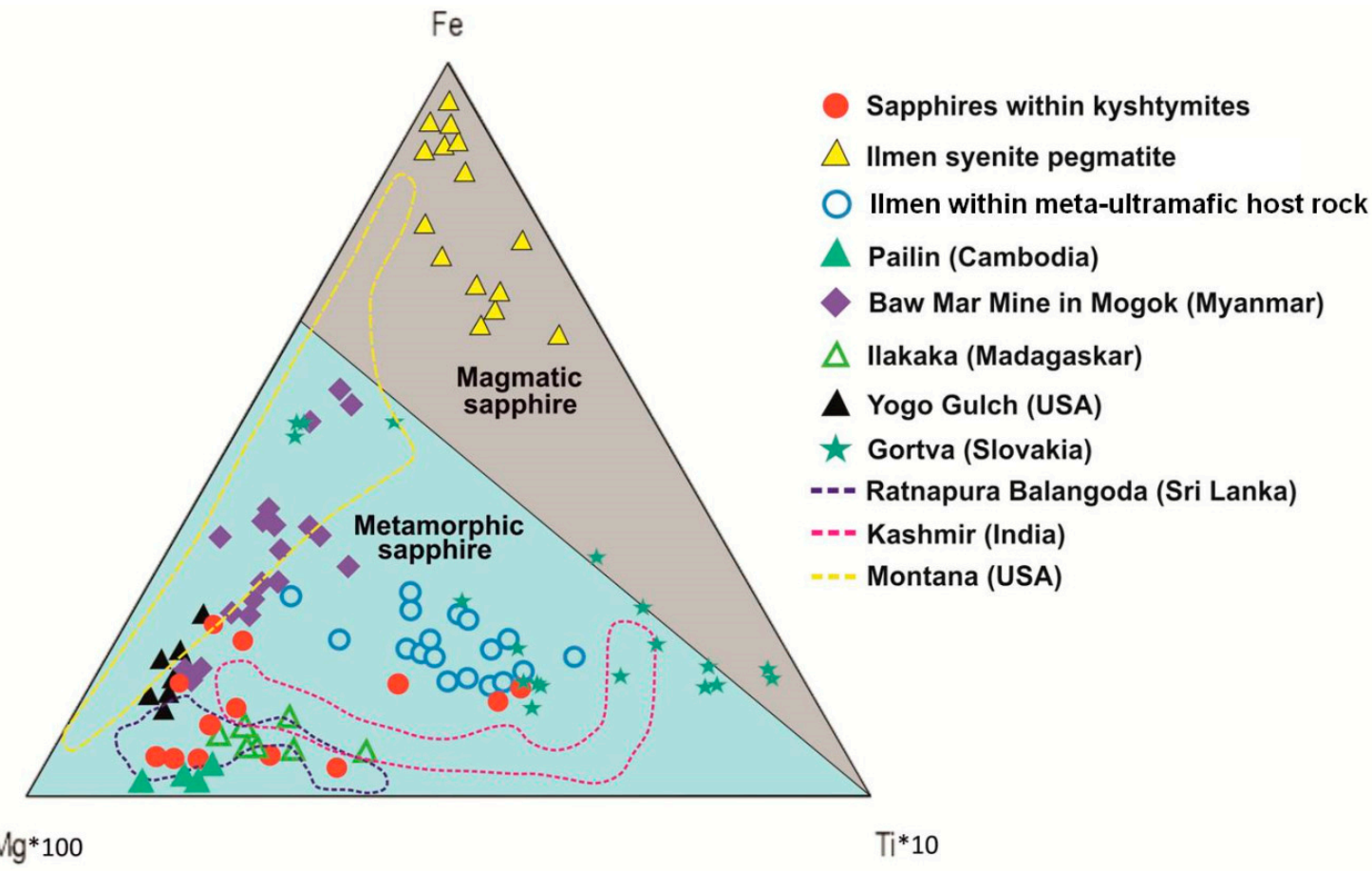

Figure 7. A Fe-Mg*100-Ti*10 ternary plot modified after Peucat et al. (2007) [35] of corundum-sapphire within kyshtymites, Ilmen sapphires within syenite pegmatites [2], Ilmen sapphires within the meta-ultramafic host rocks [3], and sapphire deposits from other regions after [35]: Pailin (Cambodia), Baw Mar Mine in Mogok (Myanmar), Ilakaka (Madaskar), Ratnapura and Balangoda (Sri lanka), Kasmir (India), and Yogo Gulch (USA). The plot of Gortva sapphire (Slovakia) is after Uher et al. (2012) [38] and Montana (USA) sapphires are after Zwaan et al. (2015) [37].

On the Fe-Cr*10-Ga*100 ternary plot (Figure 10), the sapphires from kyshtymites fall in the "magmatic field" similar to those "magmatic" sapphires from Australia [36] likely due to intermediate Fe and Ga contents, and absence of Cr values. However, they were plotted to "metasomatic" and 
"plumasitic" fields on discriminant factors diagram by Giuliani [40] (Figure 11), as in the case of those from Ilmen metasomatites within meta-ultramafic host rocks [3].

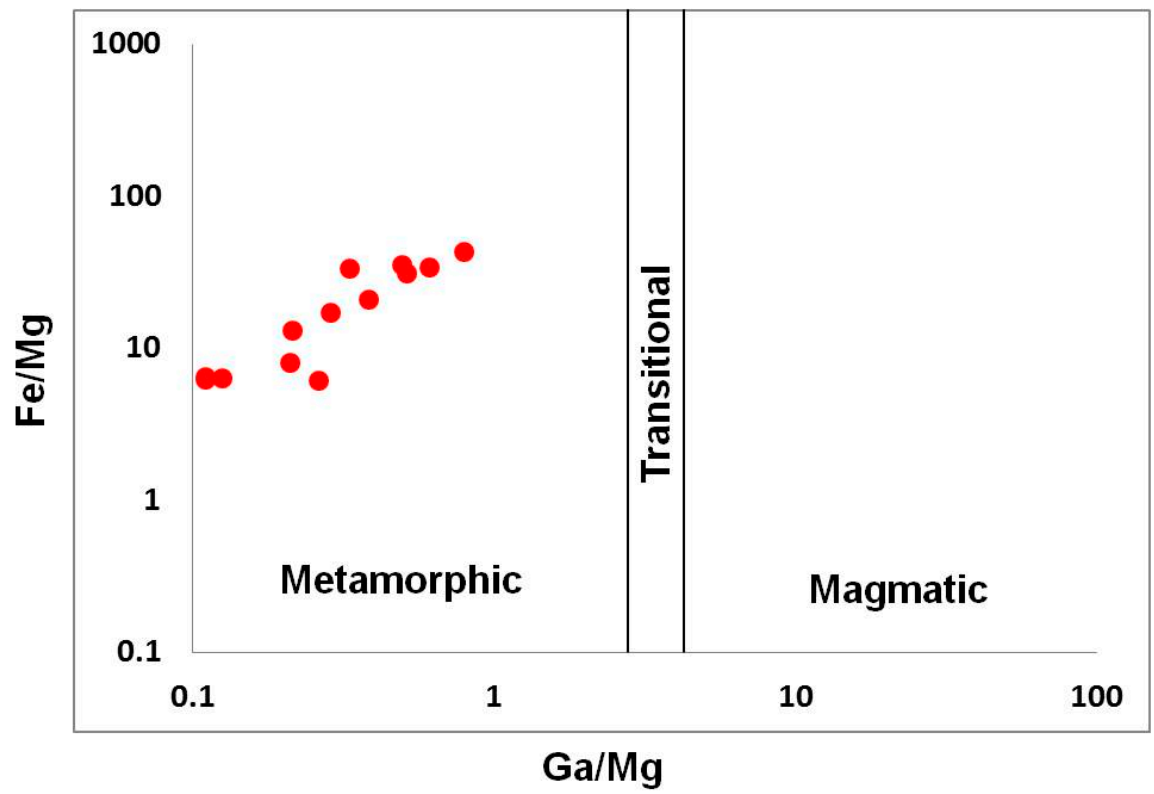

Figure 8. Fe/Mg vs. Ga/Mg discrimination diagram modified after [35,36].

Blue sapphires within kyshtymites overlap the "metasomatic" fields on $\mathrm{FeO}-\mathrm{Cr}_{2} \mathrm{O}_{3}-\mathrm{MgO}-$ $\mathrm{V}_{2} \mathrm{O}_{3}$ vs. $\mathrm{FeO}+\mathrm{TiO}_{2}+\mathrm{Ga}_{2} \mathrm{O}_{3}$ discriminant diagram (Figure 9) by [35] as in case of those sapphires within Ilmen syenite pegmatites, Ilmen sapphires within meta-ultramafic rocks, sapphires from Gortva syenite xenoliths within alkali basalts [38], and sapphires from lamphrophiric dyke in Yogo Gulch [39].

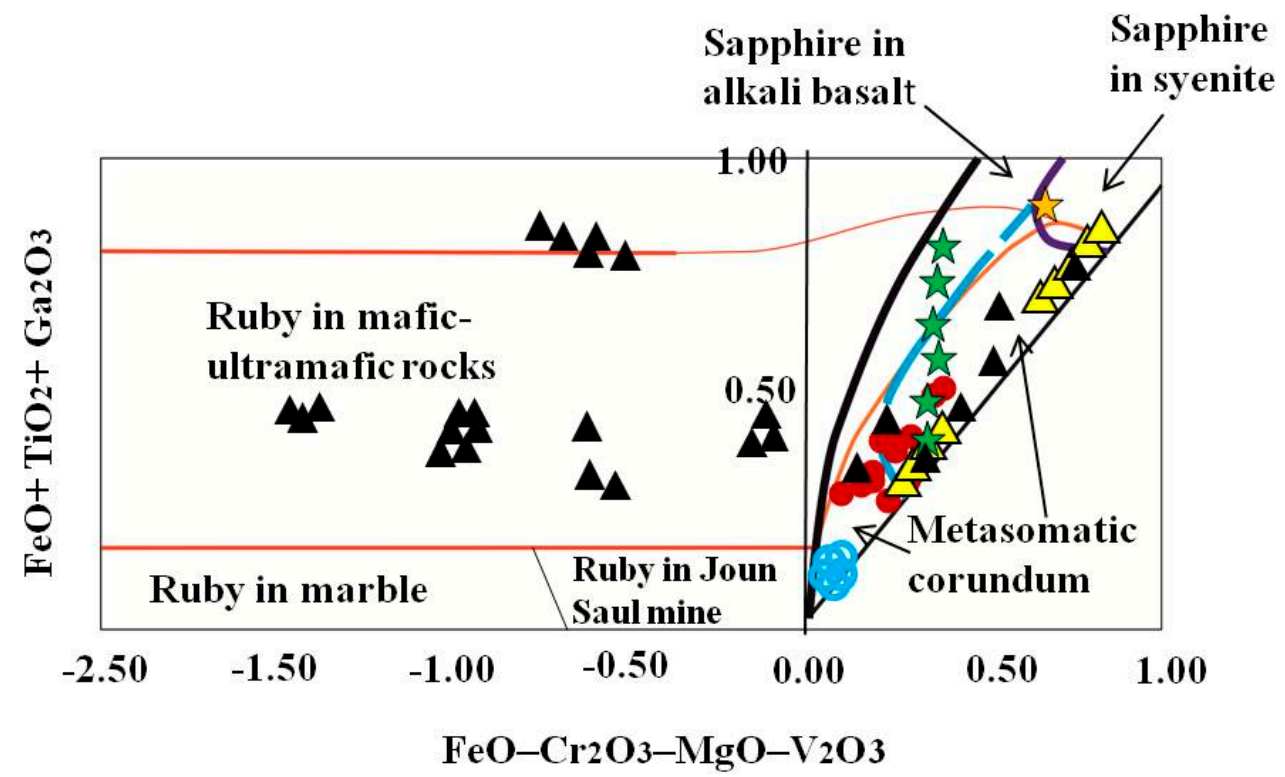

Figure 9. A FeO $-\mathrm{Cr}_{2} \mathrm{O}_{3}-\mathrm{MgO}-\mathrm{V}_{2} \mathrm{O}_{3}$ versus $\mathrm{FeO}+\mathrm{TiO}_{2}+\mathrm{Ga}_{2} \mathrm{O}_{3}$ discriminant diagram (wt. \%) is modified after Giuliani et al. (2014) [40] with extended "magmatic/syenitic" field with plotted corundum-sapphire within kyshtymites (red circles), Ilmen sapphires within syenite pegmatites (yellow triangles) [2], and within the meta-ultramafic host rocks (blue circles) [3]. The data on sapphires associated with xenoliths in alkali basalts (Gortva in Slovakia-green star; Loch Roag in Scotland-yellow star) were modified after Uher et al. (2012) [38]. The data on sapphires associated with ultramafic lamprophyre dike in Yogo Gulch (USA) (black triangles) are after [39]. Blue dotted line shows the extension of "magmatic/syenitic" sapphire field. 


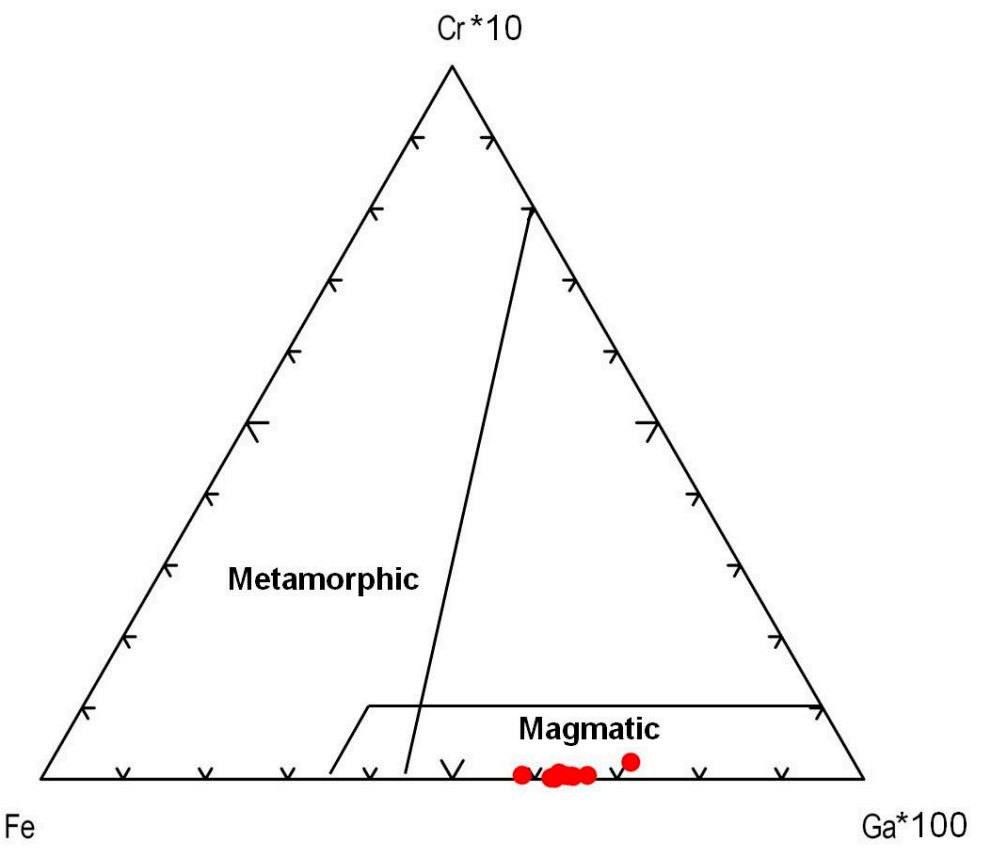

Figure 10. A Fe-Cr*10-Ga*100 ternary plot modified after Sutherland et al. (2009) [36].

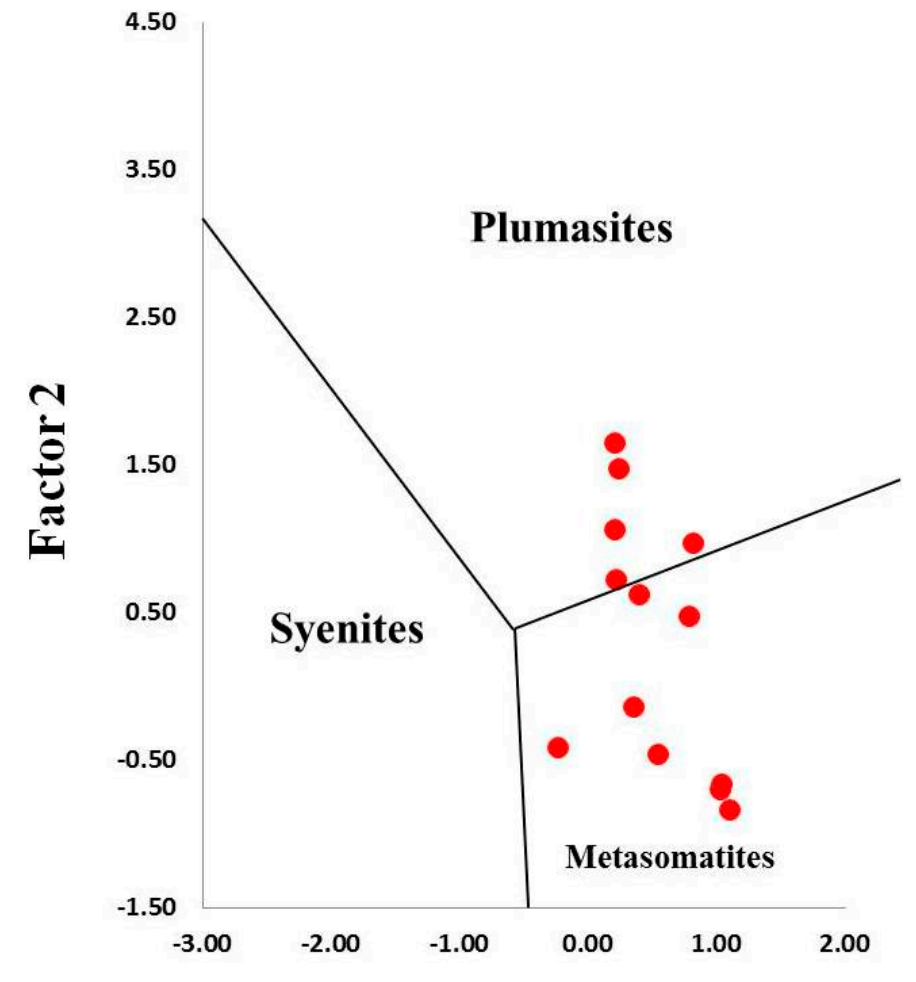

Factor 1

Figure 11. Discriminant factor diagram for identification of sapphire origin modified after Giuliani et al. (2014) [40].

\subsection{Whole Rock Geochemistry of Kyshtymites and Elements Mobility}

Major elements of kyshtymites measured by EDXRF are reported in Table S7. Kyshtymites have high $\mathrm{Al}_{2} \mathrm{O}_{3}$ (34.76-42.94 wt. \%), $\mathrm{Na}_{2} \mathrm{O}$ (0.82-4.01 wt. \%), and $\mathrm{K}_{2} \mathrm{O}(0.50-1.29$ wt. \%), but low $\mathrm{SiO}_{2}$ content (40.84-42.72 wt. \%) as well as variable $\mathrm{CaO}(5.89-15.79$ wt. \%) when compared with 
those of meta-ultramafic host rocks. Kyshtymites are characterized by low concentration of $\mathrm{Fe}_{2} \mathrm{O}_{3}$ (0.12-1.32 wt. \%), $\mathrm{MgO}\left(0.60-2.86\right.$ wt. \%), and $\mathrm{TiO}_{2}(0.04-0.15$ wt. \%).

Meta-ultramafic host rocks are enriched in $\mathrm{SiO}_{2}$ (69.72 wt. \%), $\mathrm{MgO}\left(17.97\right.$ wt. \%), and $\mathrm{Fe}_{2} \mathrm{O}_{3}$ (6.22 wt. \%), while depleted in $\mathrm{CaO}$ (up to $0.25 \mathrm{wt}$. \%), $\mathrm{Al}_{2} \mathrm{O}_{3}$ (up to $1.18 \mathrm{wt}$ \%), and alkaline elements $\left(\mathrm{Na}_{2} \mathrm{O}+\mathrm{K}_{2} \mathrm{O}\right.$ is 0.24 wt. \%). The reaction rim between kyshtymites and meta-ultramafic host rocks also contains more $\mathrm{MgO}\left(28.08\right.$ wt. \%), $\mathrm{Fe}_{2} \mathrm{O}_{3}\left(6.72\right.$ wt. \%), and $\mathrm{SiO}_{2}\left(45.09\right.$ wt. \%) and less $\mathrm{Al}_{2} \mathrm{O}_{3}$ (4.29 wt. \%), $\mathrm{CaO}\left(0.42\right.$ wt. \%), and alkaline elements $\left(\mathrm{Na}_{2} \mathrm{O}+\mathrm{K}_{2}\right.$ is 0.14 wt. \%) compared to those of kyshtymites. The concentration of $\mathrm{TiO}_{2}$ was below the detection limit (Table S7, Figure 12).

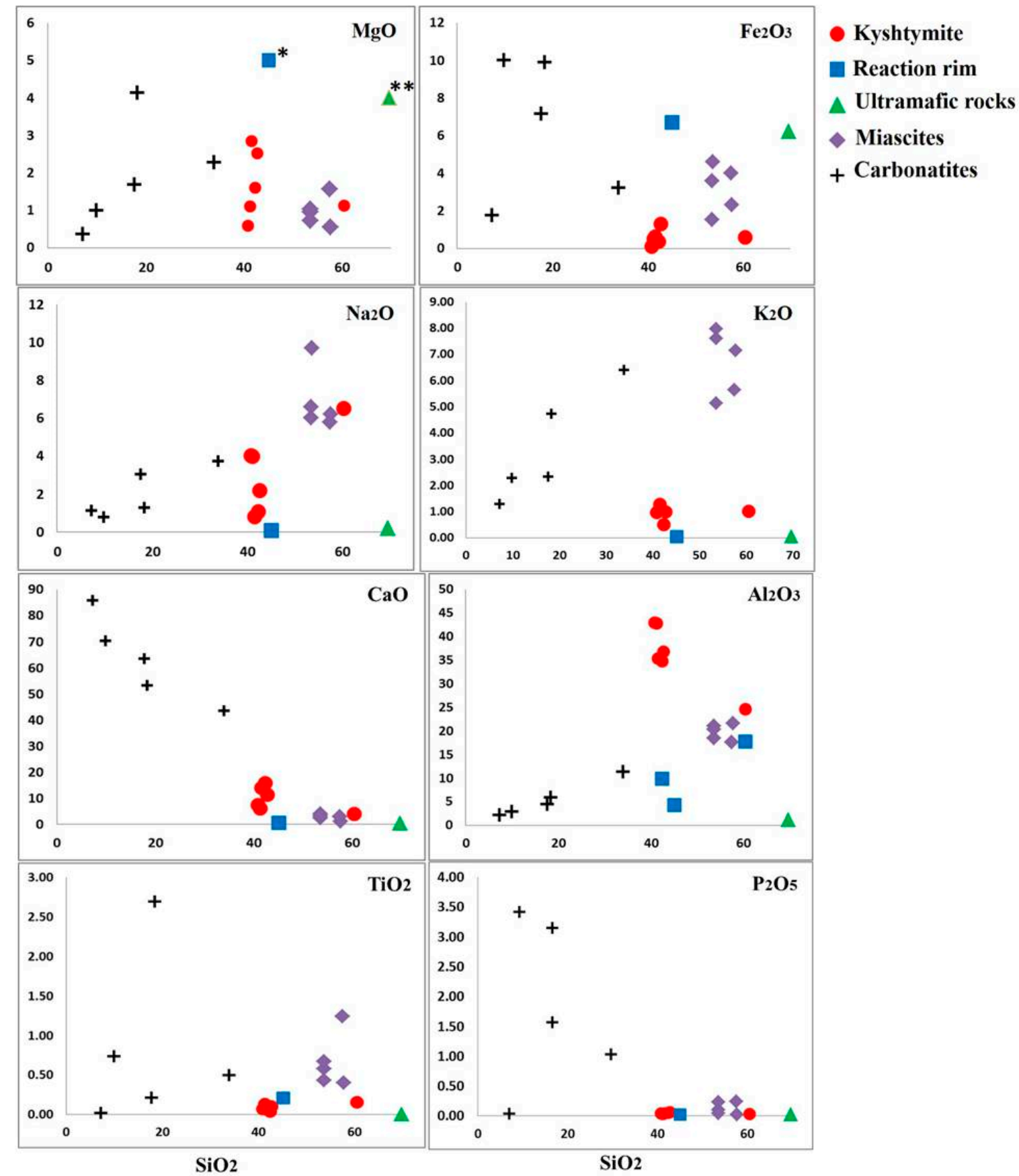

Figure 12. Harker diagrams for analyzed kyshtymites, reaction rim $\left({ }^{*} \mathrm{MgO}, 28.08\right.$ wt. \%) between kyshymites and meta-ultramafic host rocks, meta-ultramafic host rocks (** MgO, 17.97 wt. \%), miascites, and carbonatites of Vishnevogorsky complex (chemistry of miascites and carbonatites is modified after Nedosekova et al. (2009) [18]. 
On the chondrite-normalized REE spider diagram, the main trend is the enrichment of the LREE comparing to the HREE (Figure 13). This trend is similar to those detected in nepheline syenites (miascites) and carbonatites of Vishnevogorsky complex [18]. However, kyshtymites are more enriched in REE than some miascites, and depleted in REE when compared to carbonatites (Figure 13). Some samples of kyshtymites show positive Eu patterns.

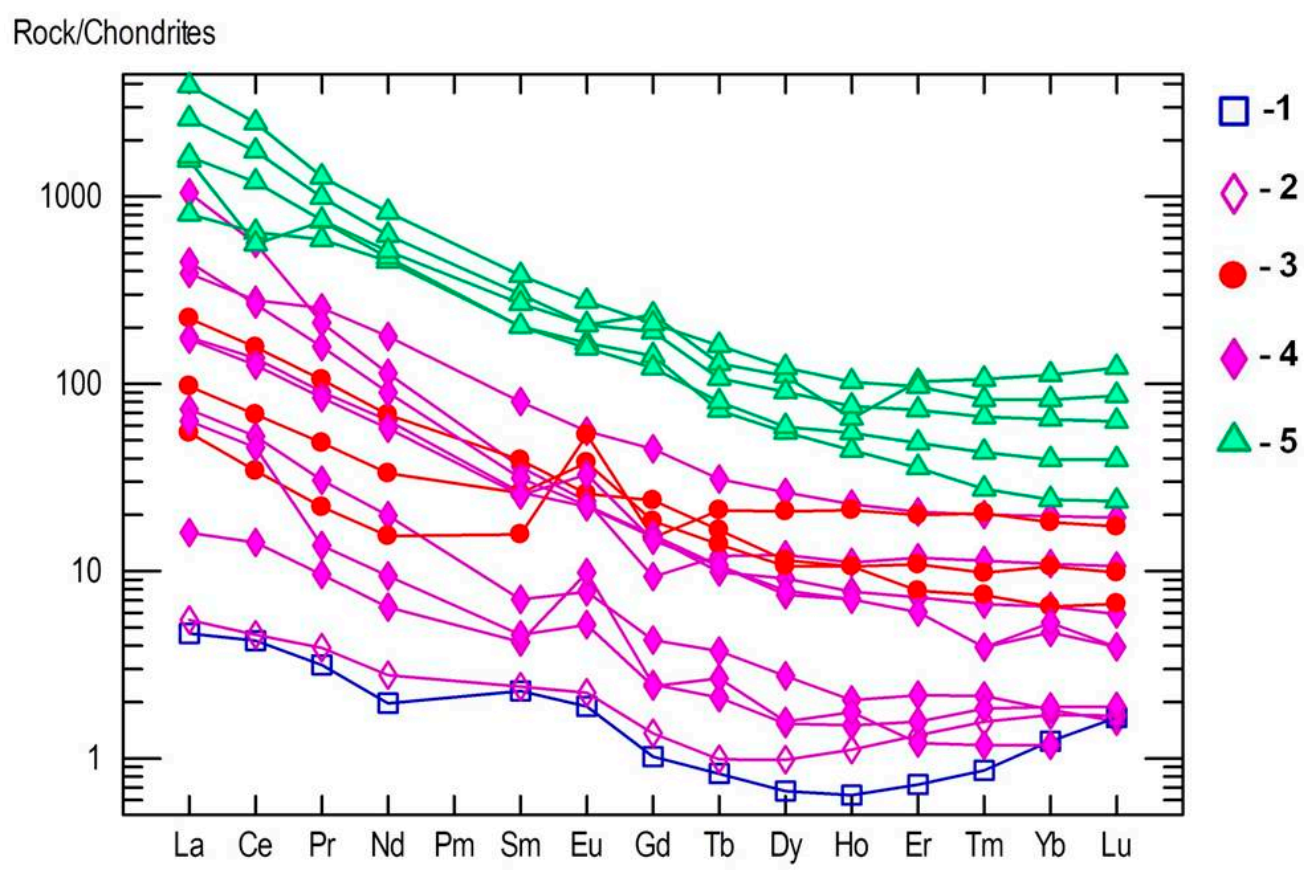

Figure 13. Chondrite-normalized REE spider diagram for the reaction rim between kyshymites and meta-ultramafic host rock (blue squares-1), meta-ultramafic host rocks (purple diamonds-2), kyshtymites (red circles-3), miascites (purple diamonds-4), and carbonatites (green triangles-5) of the Ilmenogorsky-Vishnevogorsky complex modified after [18] and Medvedeva E.V. (unpublished data); REE values in chondrite are after [41].

\subsection{Trace Element Chemistry of Zircons and In Situ LA-ICP-MS U-Pb Zircon Geochronology}

Nine zircon grains syngenetic with the sapphires from the kyshtymite sample 8-K were chosen for trace-elements measurements (Table S8) and in situ LA-ICP-MS U-Pb geochronological research (Table S9). The zircon grains ranged from about $50 \mu \mathrm{m} \times 50 \mu \mathrm{m}$ to about $100 \mu \mathrm{m} \times 200 \mu \mathrm{m}$ and showed common "magmatic" oscillatory zonation [42] visible in cathodoluminiscence images and maps in average weighted atomic numbers (Figure S1). Yellow and orange colors on the maps in Figure S1 correlate with the higher $U$ and Th contents in zircons (see Table S8).

The REE spider diagram shows enrichment in HREE relative to LREE which is common for magmatic zircons [43] (Figure 14 and Figure S2). However, the zircons from kyshtymites show significantly higher values for most REE except for $\mathrm{Tm}, \mathrm{Yb}$ and $\mathrm{Lu}$. The U/Th ratio in studied zircons varies from 0.05 to 0.60 as in zircons from nepheline syenites (miascites) and carbonatites [43] with high Hf content of 6845-17482 $\mu \mathrm{g} / \mathrm{g}$ (in the range of Hf values detected in zircon inclusions within sapphires, see Table S4), and Y concentration of 380-2370 $\mu \mathrm{g} / \mathrm{g}$. Zircons are also characterized by a positive Ce pattern $\mathrm{Ce} / \mathrm{Ce}^{*}=1.39-27.36$, whereas Eu pattern is absent $\left(\mathrm{Eu} / \mathrm{Eu}^{*}=0.35-1.04\right)$. Titanium concentrations were below the detection limit except for 4 measurements with contents of $43-182 \mu \mathrm{g} / \mathrm{g}$. One spot showed $2523 \mu \mathrm{g} / \mathrm{g}$ of Ti, most likely due to the ablation of inclusions. The kyshtymite crystallization temperature calculated by Ti-in-zircon thermometer $T\left({ }^{\circ} \mathrm{C}\right)_{\text {zircon }}=\frac{5080 \pm 30}{(6.01 \pm 0.03)-\log (\mathrm{Ti}, \mu \mathrm{g} / \mathrm{g})}$ -273 [44] of three spots showed the temperatures of about $890-920 \pm 30^{\circ} \mathrm{C}$. 


\section{Zircon/Chondrites}

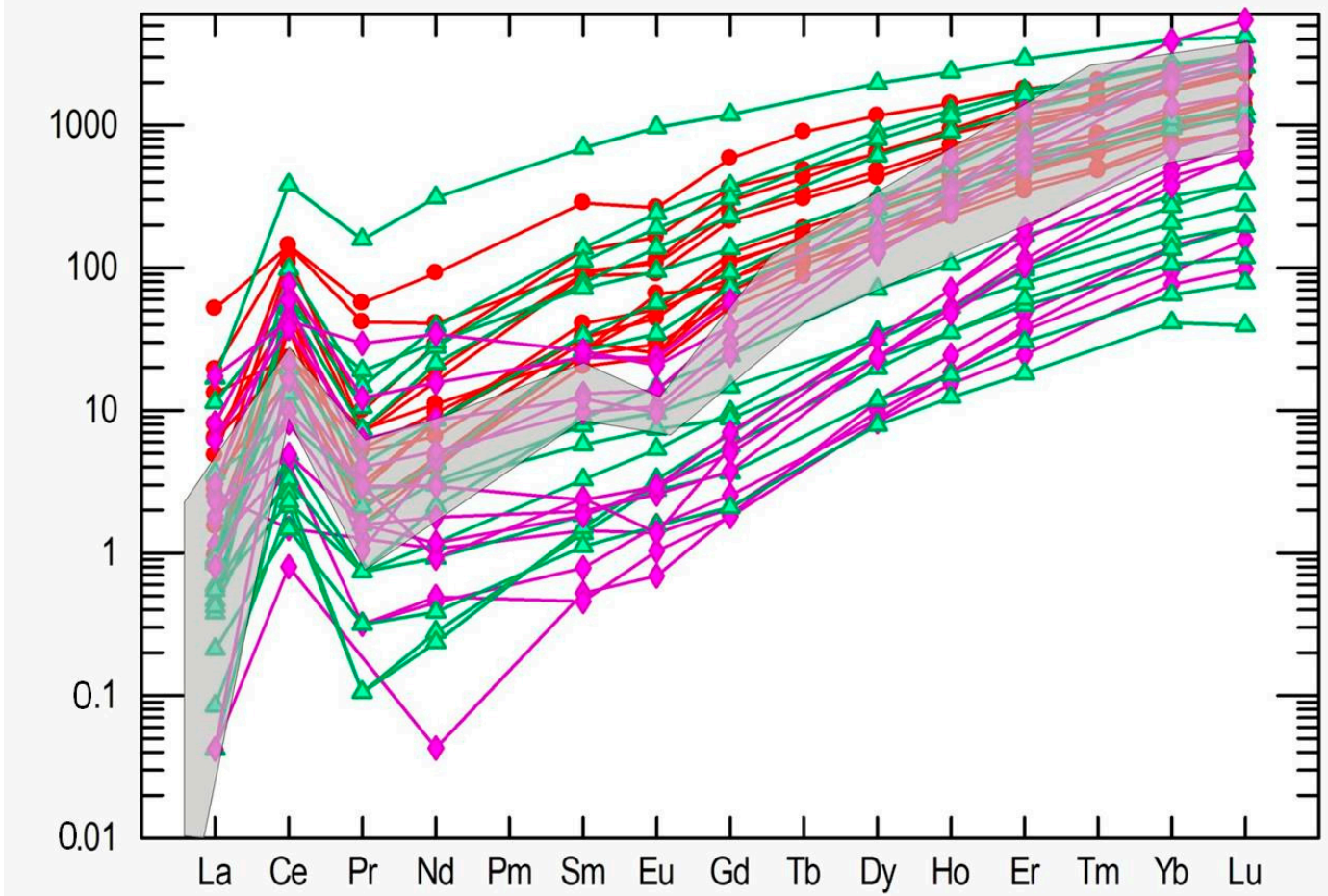

Figure 14. Chondrite-normalized concentration of REE in studied zircons from kyshtymites (samples 8-K-bold red circles), miascites (bold purple diamonds), and carbonatites (bold green triangles) of the Ilmenogorsky-Vishnevogorsky complex modified after (REE data on miascites and carbonatites are after [45]). Data on REE in chondrite are after [41]. Grey area is common REE distribution in magmatic zircons by Belousova et al. (2002) [43].

Twenty spots ablated on zircons during in situ LA-ICP-MS U-Pb geochronological measurements showed the stable ablation signal (cf. Table S8) indicating a homogeneous isotopic composition of the ablated volume. Eleven spots gave the Concordia age at $294 \pm 6 \mathrm{Ma}$. Six spots showed the older Concordia age at $334 \pm 10 \mathrm{Ma}$, which is common for the core areas of magmatic zircons (Figure S1). This older age was previously detected in zircons from carbonatites and nepheline syenites (miascites) of Ilmenogorsky-Vishnevogorsky complex [21-23,45] and is synchronous with the Hercynian metamorphism in this area [20,24] (Figure 15). Three spots were found to be in the Discordia, which is likely due to the later higher temperature event. 


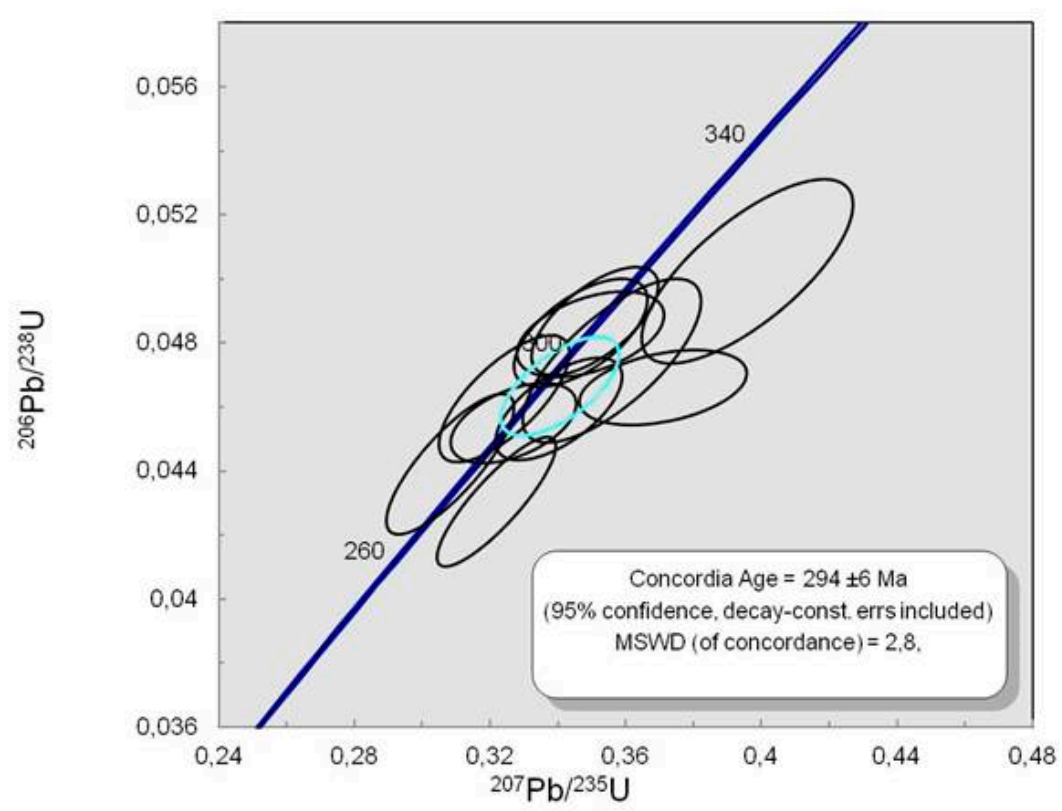

a.

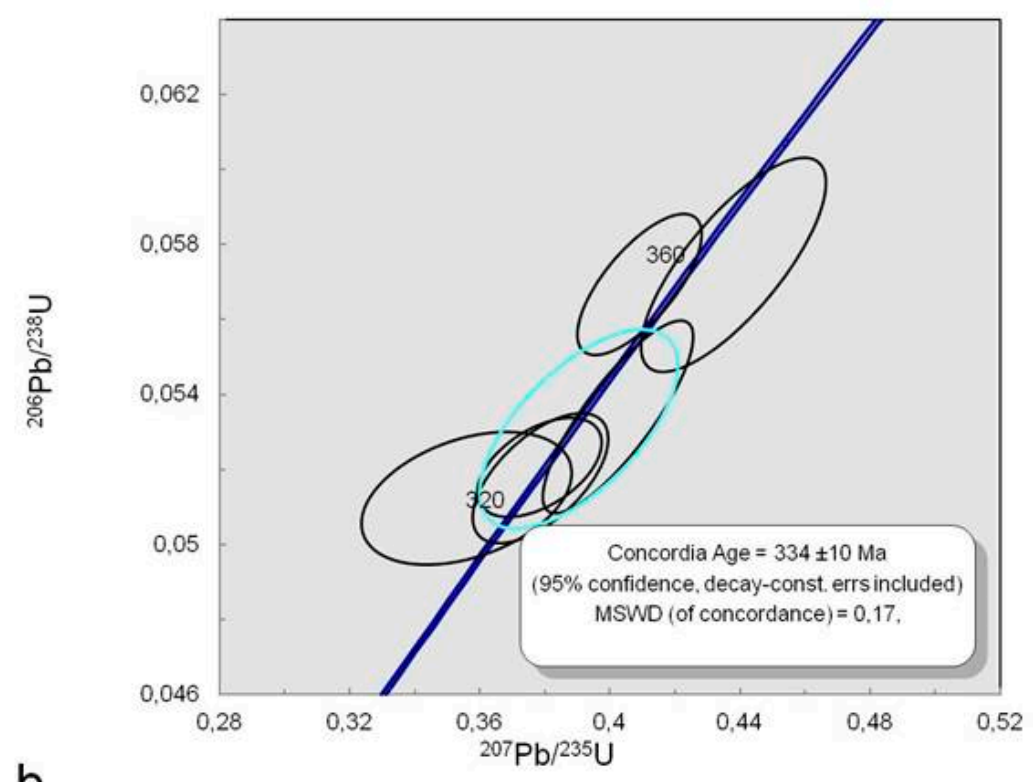

Figure 15. Concordia diagram for zircons from kyshtymite sample 8-K: (a) Concordia ages at $294 \pm 6 \mathrm{Ma}$; and (b) $334 \pm 10 \mathrm{Ma}$.

\section{Discussion}

\subsection{Genetic Models of Corundum Anorthosites-Kyshtymites}

There are several hypotheses about the origin of anorthosite-kyshtymites in South Urals, however, most of them are controversial. For instance, Fersman [46] considered kyshtymites as a product of granitic pegmatite desilication due to interaction with meta-ultramafic host rocks. According to Fersman's theory, an excess of alumina in melt crystalized in the form of corundum, and the reactive rims with biotite (phlogopite), actinolite, chlorite, and talc formed at a contact zone.

Fersman's hypothesis was criticized by Lodochnikov [47], pointing out the similar reaction rims at a contact of meta-ultramafites to the older sedimentary or igneous rocks with the absence of kyshtymites. According to Lodochnikov's idea, corundum anorthosites are hydrothermal formations, while active 
mineral-forming gas-liquid solutions are associated with the meta-ultramafites themselves. Later, Korzhinsky [48] put forward a hypothesis about the bimetasomatic origin of anorthositic veins with corundum under the influence of granite post-magmatic solutions intruded later than meta-ultramafic rocks. However, none of these theories have been confirmed during the exploration of deposit as there was no clear indication of any hydrothermal processes occurred here (e.g., the presence of dispersion halos, hydrothermal transformation of the host rocks, mineralization that determines the primary mineral zonation of hydrothermal deposits were not observed there).

The problem of the kyshtymite genesis was extensively described by Kolesnik for the Borzovsky kyshtymite occurrence (an analogue of the 5th versta deposit) [16,17]. Kolesnik suggested that the formation of kyshtymites is associated with metasomatic processes occurring during intrusion of granite dykes into ultramafic rocks. The development of corundum anorthosite replacing aplite-like granite dyke with sections of the pegmatoid structure at contact with the granite gneisses was considered as a possible formation mechanism [14]. However, this hypothesis was not supported during the exploration of deposits, because the source of aluminum, as well as calcium, required for the formation of corundum anorthosite -kyshtymites, is still debatable.

Our previous studies have shown a possible genetic link between kyshtymites (corundum anorthosites), miascites (nepheline syenites), and carbonatites of the Ilmenogorsky-Vishnevogorsky complex [25]: similar REE patterns, i.e., enrichment of LREE compared to HREE (Figure 13); anomalies in $\mathrm{U}, \mathrm{Nb}, \mathrm{P}$; , Sr, and Ti (Figure S3); moderate and highly fractionated distributions of $\mathrm{REE}(\mathrm{La} / \mathrm{Yb})_{\mathrm{N}}$ $=4.20-48.12$, and a small Eu maximum $\left(\mathrm{Eu} / \mathrm{Eu}^{*}=1.02-1.32\right)$. Both miascites and kyshtymites are extremely enriched in $\mathrm{Al}_{2} \mathrm{O}_{3}$ (up to $42.94 \mathrm{wt}$. \% in kyshtymites and up to $22.76 \mathrm{wt}$. \% in miascites [25]). Moreover, these rocks have similar accessory minerals (i.e., Y-bearing phases, apatite group minerals, and monazite-(Ce) [49]). One elder zircon age of kyshtymites and those determined in zircons from carbonatites show similar Concordia age of ca. $334 \mathrm{Ma}$ [50] (Figure S4).

\subsection{Magmatic vs. Metamorphic Origin of Kyshtymites}

Assuming that sapphires in kyshtymites represent in situ minerals of the primary rock, their geochemical signatures can be used to decode the possible origin of the sapphire-bearing anorthosites. Several discrimination diagrams from the literature presented in Figures 6-11 provide constraints on the metamorphic vs. magmatic genesis of sapphires. According to the diagrams in Figures 6-8, sapphires from kyshtymites demonstrate metamorphic imprint, whereas plots in Figures 9-11 show that they have magmatic and metamorphic signature. Compositional profiles across sapphires (Table 1 and Figure 4) indicate existence of the core and rim zones and point to at least two events of sapphire formation. However, trace element compositions of both the rim and the core are within the variations between compositions of different sapphire grains. Hence, observed zonation does not provide any additional key to unravel sapphire crystallization environment.

The ambiguity in the interpretation of sapphire origin is most probably caused by the criteria used in discriminating between magmatic and metamorphic trace element signatures proposed previously (as in Figures 6-11). Recent studies have discovered transitional groups of sapphires having trace element compositions which are located between the proposed end-members on the discrimination diagrams and which are difficult to classify [35,38,51]. For instance, recently published data on geochemistry of sapphires with obvious magmatic origin like those from Gortva syenite xenoliths within alkali basalts (Slovakia) [38], sapphires from lamphrophiric dyke in Yogo Gulch (USA) [39], sapphires from syenite pegmatites of Ilmen Mountains (South Urals of Russia) [2] indicate that the compositions of "syenitic/magmatic" sapphires lie within the nominally "metasomatic" field (Figure 9). The magmatic origin of those rocks is also confirmed by the $\delta^{18} \mathrm{O}$ data. The $\delta{ }^{18} \mathrm{O}$ value of the blue sapphire from xenolith of Gortva is $5.1 \pm 0.1 \%$ [38] fits with the $\delta^{18} \mathrm{O}$ range of sapphires associated with syenites/anorthoclasites [52]. The $\delta{ }^{18} \mathrm{O}$ values of sapphires from lamphrophiric dyke in Yogo Gulch (Montana, USA) showed 5.4-6.8\% [39] overlapping the field defined for sapphires from lamprophyres $(4.5-7.0 \%$ o $)$ and sapphires from syenites $(5.2-7.8 \%$ o $)$ [52]. Sapphires from syenite pegmatite of the 
Ilmen Mountains showed $\delta^{18} \mathrm{O}$ about $4.3 \%$, i.e., in range defined for magmatic rocks (lamprophyre, basalt, and syenite) [53]. Magmatic origin of sapphires from Yogo Gulch, Gortva, and Ilmen syenite pegmatites is also confirmed by presence of syngenetic inclusions of primary magmatic minerals (Table S10). In fact, the presence of mainly Ca-plagioclase solid inclusions within sapphires from Yogo and in the lamprophyre xenoliths, as in case of kyshtymites, as well as trachytic melt inclusions indicates that a slab-related troctolitic or anorthositic protolith may be involved in their formation [39]. Plagioclase, as in case of kyshtymites, and alkali feldspar, as in case of Ilmen syenite pegmatites, were found in mineral association, while zircon, spinel, monazite-(Ce), ilmenite, and Y-REE phase were identified as solid inclusions within sapphires from Gortva. Columbite-(Fe), zircon, minerals of alkali feldspar group, monazite-(Ce), sub-micron grains of uraninite, muscovite, diaspore, and ilmenite were identified as syngenetic solid inclusions within the blue sapphire from syenite pegmatites of Ilmenogorsky complex (mines 298 and 349) [2,35]. Thus, the "magmatic/syenitic" field in Figure 9 could be extended toward the low boundary of plot with Ilmen sapphires within syenite pegmatites.

On the $\mathrm{Fe}$ vs. $\mathrm{Ga} / \mathrm{Mg}$ diagram and $\mathrm{Fe}-\mathrm{Mg}^{*} 100-\mathrm{Ti}^{*} 10$ ternary plot (Figures 6 and 7), sapphires from kyshtymites plotted in the "metamorphic" field overlapping those from lamphrophiric dyke of Yogo Gulch and Gortva syenite xenoliths, the igneous nature of which was shown above. Besides they are also overlap Pailin (Cambodia) placer sapphire xenocrysts trapped by alkali basalts. The $\delta^{18} \mathrm{O}$ of last is $7.1-7.8 \%$, which is also in range defined for magmatic sapphire in syenite [53]. Moreover, sapphires from Pailin deposit [54] contain inclusions of pyrochlore, columbite-(Fe), goethite, zircon, monazite-(Ce), and rutile $[55,56]$ as in case of Ilmen syenite pegmatites [2,35], while plagioclase identified there as well is also the case of kyshtymites. Sapphires from kyshtymites and Ilmen syenite pegmatites overlap with those from alluvial placer deposit in Montana (USA). Besides, anatase, Ca-rich plagioclase (Raman spectra of them match with anorthite and bytownite) and alkali feldspar (Raman spectra of them match with orthoclase) as in the case of Ilmen syenite pegmatites, along with rutile, ilmenite, monazite-(Ce), apatite group minerals, etc., were identified as solid inclusions within Montana sapphires (see Table S10).

These observations indicate that the existing discrimination diagrams do not provide a clear answer on the sapphire origin. In this sense, the "metamorphic" signature of the sapphires from kyshtymites could be only apparent and incorrect. Thus, based on the available classification of trace element compositions in sapphires, it is currently impossible to unambiguously determine the origin of kyshtymites.

Another possible genetic tool is the geochemistry of zircons from kyshtymites. The zircons demonstrate a clear REE pattern typical for magmatic zircons and similar to that found in zircons from syenites and carbonaties which are obviously magmatic rocks [45] (Figure 14 and Figure S2). Furthermore, both syenites and carbonatites contain also other types of zircons, which are interpreted as metamorphic, with significantly different trace element patterns (Figures 14 and 15). Since kyshtymites are syngenetic to magmatic syenites and carbonaties (see Figure 13), their REE signature of zircons can imply a magmatic origin of anorthosites. Further analysis of trace element compositions of zircons also shows magmatic origin within the continental crust (Figures 16 and 17). 


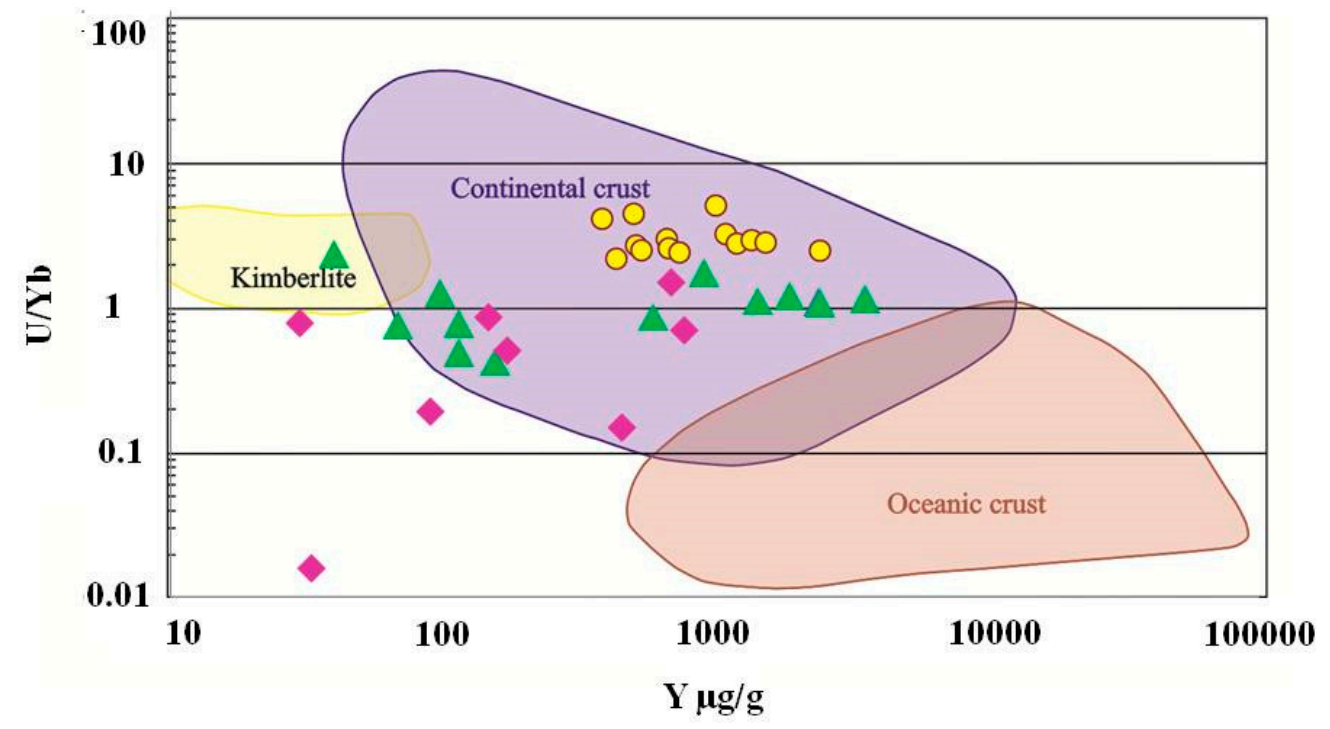

Figure 16. U/Nb vs. Y discriminant diagram of zircons from kyshtimtes (bold yellow circles), miascites (bold purple diamonds), and carbonatites (bold green triangles) of the Ilmenogorsky-Vishnevogorsky complex (the chemistry on miascites and carbonatites is modified after [45]). Fields for continental and oceanic crust, and kimberlite are from Grimes et al. (2007) [57].

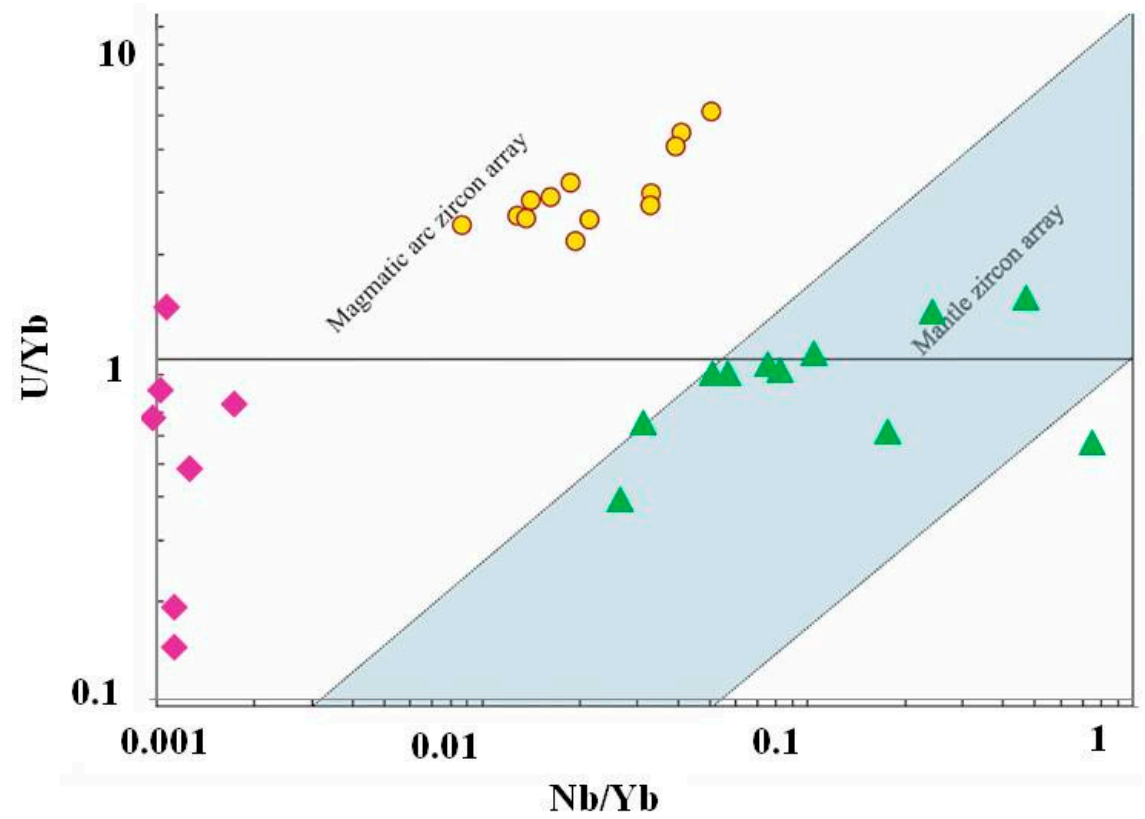

Figure 17. $\mathrm{U} / \mathrm{Nb}$ vs. $\mathrm{Nb} / \mathrm{Yb}$ discriminant diagram of zircons from kyshtimtes (bold yellow circles), miascites (bold purple diamonds), and carbonatites (bold green triangles) of the IlmenogorskyVishnevogorsky complex (the chemistry on miascites and carbonatites is modified after [45]); fields for mantle and magmatic arc arrays are from Grimes et al. (2015) [58].

On the chondrite-normalized REE diagram for zircons (Figure 16), REE distributions show the main trend of enrichment in HREE compared to LREE with Ce pattern, which is similar to those observed in miascites and carbotanites of Ilmenogorsky-Vishnevogorsky complex. Positive patterns of Th, U, Hf, and Ta are also observed in chondrite-normalized REE diagrams (Figure S3).

Thus, formation of "magmatic" corundum-blue sapphire anorthosites could occur, likely during at least two stages. In the first stage, about 450-420 Ma [21-23,50], primary anorthosites formed as cumulates in the magmatic chamber, along with miascites and carbonatites of the IlmenogorskyVishnevogorsky complex, with likely more Ca-rich plagioclase in mineral association. Formation of 
cumulates in magmatic chamber on the later stage in excess of $\mathrm{H}_{2} \mathrm{O}$ was confirmed by experimental studies [59], whereas another study showed formation of cumulates at the top of magmatic chamber due to the lower density than the rest of magma [60]. Later, at 300-285 Ma, primary anorthositic cumulates probably could be re-melted during the collision process. Plagioclase recrystallized to more Ca-poor member, whereas the excess of aluminum crystallized in form of corundum, while sodium probably came from nepheline syenites (miascites).

However, even though zircons demonstrate clear evidence of magmatic origin, their signature may not represent the genesis of anothosites. Zircons are known as very stable and inert minerals and, hence, they could be inherited in anorthosites from another primary rock. Since both syngenetic syenites and carbonataites contain zircons, they can be a source of magmatic zircons in the system. $\mathrm{On} \mathrm{U} / \mathrm{Nb}$ vs. Y discriminant diagram (Figure 16), zircons from nepheline syenites (miascites) and carbonatites are plotted on the "continental crust" fields despite on their mantle origin [45] overlapping zircons from kyshtymites. On $\mathrm{U} / \mathrm{Nb}$ vs. $\mathrm{Nb} / \mathrm{Yb}$ discriminant diagram, zircons from miascites and kyshtymites are also plotted to "magmatic arc" field (Figure 17). In other words, the zircons in kyshtymites can be magmatic, but the host rock can be produced by a metamorphic process. Such a process must be a relatively low temperature process to preserve original zircons unaffected. The Ti-in-zircon thermomentry provides temperature estimates of about $890-920^{\circ} \mathrm{C}$, which is close to or below the closure temperature of the U-Pb geochronometer in zircons [61]. On the other hand, the $\mathrm{U}-\mathrm{Pb}$ age determinations show only few discordant zircons (Figure 16) which could be affected by high-temperature events (either magmatic or metamorphic). Most zircons demonstrate concordant ages indicating that after their formation they were not exposed to high temperatures. Thus, compositions of zircons are also not an ultimate tool to reconstruct the origin of kyshtymites.

Typically, it is believed that anorthosites are formed by differentiation of mafic magmas when plagioclases become buoyant due to density contrast and accumulate at the roof of the magma chamber [58]. Such a process would require a relatively large volume of magma to produce plagioclase cumulates. The dimensions of kyshtymite anorthositic veins are quite small with the length from 15 to $70 \mathrm{~m}$ and thickness from 0.1 to $3 \mathrm{~m}$, which are not realistic for anorthositic body of magmatic origin. Furthermore, formation of anorthosites by re-melting processes during orogenic events is also questionable as temperatures recorded by zircons are relatively low and obviously not enough to melt anorthite-rich substrate/rock.

The ages of $294 \pm 6 \mathrm{Ma}$ as determined by zircon geochronology correspond to the ages of Hercynian metamorphism during collision events in the area of Ilmenogorsky-Vishnevogorsky complex. Thus, formation of kyshtymites could also happen due to metamorphic processes. The kyshtymite vein shown in Figure 2 is located within the meta-ultramafic rocks separated by reaction rim consisting mostly of chrysotile-asbestos [62]. The ultra-mafic rocks originally having an orthopyroxenitic composition are strongly metamorphosed and enriched in silica (see Figure 12). This silica-enrichment process is likely linked to the Caledonian metamorphism [63] accompanied by the silicon metasomatism and partial removal of magnesium. Moreover, the excess of Si could also occur likely during the metamorphic re-working and desilication of carbonatites (see the discussion below). The importance of buffering capacity of ultramafic host rocks with respect to silica has been shown in ruby deposit from the Greenland [64]. The similar process observed on another corundum-blue sapphire-bearing deposit within meta-ultramafic host rocks (mine 418) in Ilmenogorsky complex [3].

However, the genesis of the contact zone is difficult to reconstruct since there is no clear evidence for a magmatic contact and there is no indication for any metasomatic zonation. Kyshtymites demonstrate $\mathrm{Rb}-\mathrm{Sr}$ and $\mathrm{Sm}-\mathrm{Nd}$ isotopic signatures $\left({ }^{87} \mathrm{Sr} /{ }^{86} \mathrm{Sr}\right.$ of $0.70637-0.706936$ and $\varepsilon \mathrm{Nd}$ from -5.3 to -10.7) corresponding to the signature of the low-crustal material [25], whereas miascites and carbonatites show mantle-derived values [18]. The data lie on the miascites-carbonatites trend of the Ilmenogorsky-Vishnevogorsky complex and show increasing contribution from the crust (Figure S5). The age and isotopic data could be indicative of the late stage process of kyshtymite formation related to the Hercynian metamorphic event. The main question is the initial protolith to form anorthosites. 
The geochemical features of syenites and carbonatites suggest that one of these rocks could serve as a substrate for metamorphic reactions to form anorthosites. Assuming that $\mathrm{Al}$ is mostly immobile major element and that carbonates can be decomposed by metamorphic fluids, it can be suggested that metamorphism of carbonatites can be responsible for the formation of Ca-Al-rich anorthosites. Carbonaties from Ilmenogorsky-Vishnevogorsky complex have in addition to $\mathrm{CaO}$, about 5-30 wt. \% of $\mathrm{SiO}_{2}$ and 1-11 wt. \% of $\mathrm{Al}_{2} \mathrm{O}_{3}$ on the $\mathrm{CO}_{2}$-free basis [18]. If $\mathrm{Ca}$ and $\mathrm{CO}_{2}$ are removed by the metamorphic fluids, the residue will be enriched in $\mathrm{Al}$ and Si. Assuming that host meta-ultramafic rocks can be effectively silicified and hence, consume $\mathrm{Si}$, the concentration of $\mathrm{Al}$ in former carbonatite vein can reach very high values resulting in the formation of corundum and Ca-rich plagioclases. At the later stages with decreasing temperature, muscovite and clinozoisite, which particulary replace plagioclase, could form in kyshtymite veins as a lower-temperature phases. Clinochlore crystallized at the final stage. Its formation occurred due to replacement of muscovite and the introduction of $\mathrm{Mg}$ into the system from the meta-ultramaifc host rocks by metasomatic fluids. One evidence for such a process could be a UV-Vis-NIR spectra of sapphires in one kyshtymite sample which are similar to the spectra observed for metamorphic/metasomatic sapphires.

Such a scenario would explain the metamorphic signature of newly-formed sapphires and magmatic signature of zircons inherited from parental carbonatitic rock. On the other hand, such petrogenetic history of kyshtymites is not visible in the host rocks. It is expected that intensive metamorphism and decomposition of carbonates would result in the development of metamorphic/ metasomatic zonation around kyshtymite veins and will cause significant volume changes, which is not observed.

Thus, the new geochemical data presented in this study still do not provide a final and unambiguous answer on the origin of kyshtymites and further investigations are required, e.g., oxygen isotopy of corundum is promising for clarifying the genesis of the kyshtymites.

\section{Conclusions}

Sapphires were found in situ within primary rock-anorthosites (kyshtymites) -in the 20th century. Until now, the genesis of kyshtymites remains controversial. They are located at a boundary of the Ilmenogorsky-Vishnevogorsky alkaline complex of Russia's South Urals to the north of blue sapphires in syenite pegmatites (mines 298 and 349) and of metasomatites within meta-ultramafic host rocks (mine 418).

Measured trace elements are in the range for metamorphic sapphires: 10,000 Ga/Al $>0.60-0.80$, $\mathrm{Ga} / \mathrm{Mg}$ is $0.11-0.80, \mathrm{Fe} / \mathrm{Mg}$ is $6.15-43.32, \mathrm{Cr} / \mathrm{Ga}$ is $0.01-0.32$, and $\mathrm{Fe} / \mathrm{Ti}$ is $1.08-22.95$. Sapphires are plotted to the "metamorphic" field in Fe versus $\mathrm{Ga} / \mathrm{Mg}$ and $\mathrm{Fe}-\mathrm{Mg}^{*} 100-\mathrm{Ti}^{*} 10$ diagrams. Besides, they also overlap "metasomatic" and extended "magmatic/syenitic" fields in $\mathrm{FeO}-\mathrm{Cr}_{2} \mathrm{O}_{3}-\mathrm{MgO}-\mathrm{V}_{2} \mathrm{O}_{3}$ versus $\mathrm{FeO}+\mathrm{TiO}_{2}+\mathrm{Ga}_{2} \mathrm{O}_{3}$ discriminant diagrams.

Two possible magmatic and metamorphic-metasomatic scenarios were proposed for the formation of anorthosites-kyshtymites. The magmatic formation of corundum anorthosites should take place during at least two stages. At about 450-420 Ma, primary anorthosites formed as cumulates in the magmatic chamber, along with miascites and carbonatites of the Ilmenogorsky-Vishnevogorsky complex. Further at 300-285 Ma, primary anorthositic cumulates could be re-melted during the collision process. Plagioclase recrystallized to more Ca-poor member, whereas the excess of aluminum crystallized in form of corundum. However, small sizes of anorthositic veins and obtained sub-solidus temperatures of $890-920 \pm 30{ }^{\circ} \mathrm{C}$ by Ti-in-zircon thermometry do not support the hypothesis of magmatic origin.

The second possible scenario is the formation of kyshtymites through the metamorphicmetasomatic re-working of initial carbonatites. Calcium and $\mathrm{CO}_{2}$ could be removed by metamorphic fluids, the residue would be enriched in $\mathrm{Al}$ and $\mathrm{Si}$. While meta-ultramafic host rocks consume $\mathrm{Si}$, the concentration of $\mathrm{Al}$ in former carbonatite vein can reach very high values resulting in the formation of corundum and Ca-rich plagioclases. 
Trace-element chemistry and solid inclusions identified in sapphires from kyshtymites, along with those of syenite pegmatites of Ilmenogorsky complex, provide possible genetic links with sapphires from Montana (USA), Gortva (Slovakia), and Pailin (Cambodia). However, more research is required to unravel the nature of anorthositic-syenitic protoliths that could be involved in their formation.

Supplementary Materials: The following are available online at http://www.mdpi.com/2075-163X/9/4/234/s1, Table S1. The samples and methods used in the research; Table S2. Minerals identified in association with the sapphire; Table S3. Representative compositions (wt. \%) of major minerals found in association with sapphire; Table S4. Representative compositions (wt. \%) of minor minerals found in association with sapphire; Table S5. Representative compositions (wt. \%) of the zircon inclusions in sapphire; Table S6. Chemical composition of sapphires from Ilmenogorsky-Vishnevogorsky complex and sapphire occurrences with possible anorthositic-syenitic origin. Table S7. Representative analyses of corundum-blue sapphire anorthosites-kyshtymites, meta-ultramafic host rocks, and reaction rim; Table S8. LA-ICP-MS trace-elements measurements of zircons from sample 8-K; Table S9 In situ LA-ICP-MS geochronology of zircons from sample 8-K; Table S10. Frequently detected solid inclusions and common minerals found in association with sapphires from Ilmenogorsky-Vishnevogorsky complex and sapphire occurrences with possible anorthositic-syenitic origin. Figure S1. Zircon CL images and maps in average weighted atomic numbers with the spots positions for trace-elements (No. of spots inside of circles) and U-Pb geochronological measurements (U-Pb ages inside of circles). Black, Concordia kyshtymite age; red, 6 Concordia elder ages; purple, 3 ages in Discordia. Figure S2. Chondrite-normalized concentration of REE and trace elements in studied zircons from kyshtymites (a), miascites (b), and carbonatites (c), of the Ilmenogorsky-Vishnevogorsky complex modified after [45]. Data on REE and trace elements in chondrite are after [41]. Figure S3. Trace-elements and REE distribution normalized to primitive mantle (the data on REE and trace-elements in primitive mantle are from [41]) in reaction rim (1) between kyshymites and meta-ultramafic host rock, meta-ultramafic host rocks (2), kyshtymites (3), miascites (4), and carbonatites (5) of the Ilmenogorsky-Vishnevogorsky complex modified after [18] and Medvedeva E.V (unpublished data). Figure S4. Concordia diagram for zircons from kyshtymite sample 8-K and carbonatites of Vishnevogorsky complex (sample 354 by Nedosekova [50]). Figure S5. Diagram $\varepsilon S r(T)$ vs. $\varepsilon N d(T)$ for kyshtimte and miascite of the Ilmenogorsky-Vishnevogorsky complex modified after [18,25], the diagram shows mantle reservoirs DMM, HIMU, EM1, EM2, MORB and OBI [65].

Author Contributions: M.I.F. formulated the idea of a paper, performed the petrography of kyshtymte and host rocks, designed experiments on EDXRF and WDS EMPA, assembled most of tables and figures, and wrote the manuscript; E.S.S. formulated the idea of a paper, designed experiments on Raman spectroscopy, WDS EMPA, ICP-MS, LA-ICP-MS sapphire and zircon geochemistry, and LA-ICP-MS U-Pb zircon geochronology, performed LA-ICP-MS sapphire geochemistry and its following data-reduction process, interpreted the zircon dating data and constructed Concordia diagrams, assembled some tables and figures, wrote the part of manuscript, and edited the final text of paper; R.B. supervised the LA-ICP-MS zircon geochemical and U-Pb zircon geochronological measurements, formulated the part of possible scenario for kyshtymites origin, and edited the manuscript; S.K. helped with data interpretation and editing of the manuscript; M.A.R. collected samples for research and provided the geological setting data; N.N.K. performed WSD EMPA, and produced zircon CL and BSE images and maps of average weighted atomic numbers; A.G.N. provided absorption spectra of sapphires and their interpretation; J.B. performed LA-ICP-MS zircon geochemistry and U-Pb zircon geochronology, and their following data-reduction process; and W.H. supervised the LA-ICP-MS zircon geochemical and U-Pb zircon geochronological measurements.

Funding: The research was supported by the Foundation of the President of Russian Federation (project No. MK-4459.2018.5). In situ LA-ICP-MS zircon trace-elements and geochronological measurements were supported by the German Academic Exchange Service (DAAD, No 57378441) and Stiftung zur Förderung der Edelsteinforschung of Johannes Gutenberg Universität Mainz (Germany).

Acknowledgments: The authors are grateful to Elena V. Medvedeva (Ilmen State Reserve, Russia) for the provided chemical analyses of miascites. The authors are grateful to the colleagues from GEOKHI RAS (T.G. Kuzmina, V.N. Ermolaeva, T.V. Romashova, V.A. Turkov, B.S. Semiannikov), Ya.V. Bychkova (Moscow State University, Russia), E.A. Minervina (IGEM RAS), K.Ponkratov (Renishaw Moscow), Delia Rösel (Technische Universität Bergakademie Freiberg, Germany), as well as Stephan Buhre and Tobias Häger (Johannes Gutenberg Universität Mainz, Germany) for their assistance in sample preparation and analytical studies of kyshmymites and miascites, as well as following data interpretation.

Conflicts of Interest: The authors declare no conflict of interest.

\section{References}

1. Giuliani, G.; Ohnenstetter, D.; Fallick, A.E.; Groat, L.; Fagan, A.G. The geology and genesis of gem corundum deposits. In Geology of Gem Deposits, 2nd ed.; Groat, L.A., Ed.; Mineralogical Association of Canada Short Course Series; Mineralogical Association of Canada: Tucson, AZ, USA, 2014; Volume 44, pp. $29-112$.

2. Sorokina, E.S.; Karampelas, S.; Nishanbaev, T.P.; Nikandrov, S.N.; Semiannikov, B.S. Sapphire Megacrysts in Syenite Pegmatites from the Ilmen Mountains, South Urals, Russia: New Mineralogical Data. Can. Mineral. 2017, 55, 823-843. [CrossRef] 
3. Sorokina, E.S.; Rassomakhin, M.A.; Nikandrov, S.N.; Karampelas, S.; Kononkova, N.N.; Nikolaev, A.G.; Anosova, M.O.; Orlova, A.V.; Kostitsyn, Y.A.; Kotlyarov, V.A. Origin of blue sapphire in newly discovered spinel-chlorite-muscovite rocks within meta-ultramafites of Ilmen Mountains, South Urals of Russia: Evidence from mineralogy, geochemistry, Rb-Sr and Sm-Nd isotopic data. Minerals 2019, 9, 36. [CrossRef]

4. Simonet, C.; Paquette, J.L.; Pin, C.; Lansner, B.; Fritsch, E. The Dusi (Garba Tula) sapphire deposit, Central Kenya-a unique Pan-African corundum-bearing monzonite. J. Afr. Earth Sci. 2004, 38, 401-410. [CrossRef]

5. Monchoux, P.; Fontan, F.; De Parseval, P.; Martin, R.F.; Wang, R.C. Igneous albitite dikes in orogenic lherzolites, western Pyrenees, France: a possible source for corundum and alkali feldspar xenocrysts in basaltic terranes. I. Mineralogical associations. Can. Mineral. 2006, 44, 817-842. [CrossRef]

6. Kan-Nyunt, H.P.; Karampelas, S.; Link, K.; Thu, K.; Kiefert, L.; Hardy, P. Blue sapphires from the Baw Mar Mine in Mogok. Gems Gemol. 2013, 49, 223-232. [CrossRef]

7. Khoi, N.N.; Hauzenberger, C.A.; Sutthirat, C.; Tuan, D.A.; Häger, T.; Van Nam, N. Corundum with Spinel Corona from the Tan Huong-Truc Lau Area in Northern Vietnam. Gems Gemol. 2018, 54, 4. [CrossRef]

8. Voudouris, P.; Mavrogonatos, C.; Graham, I.; Giuliani, G.; Melfos, V.; Karampelas, S.; Karantoni, V.; Wang, K.; Tarantola, A.; Zaw, K.; et al. Gem Corundum Deposits of Greece: Geology, Mineralogy and Genesis. Minerals 2018, 9, 49. [CrossRef]

9. Keulen, N.; Kalvig, P. Fingerprinting of corundum (ruby) from Fiskenæsset, West Greenland. Geol. Surv. Denmark Greenland 2013, 25, 53-56.

10. Karmakar, S.; Mukherjee, S.; Sanyal, S.; Sengupta, P. Origin of peraluminous minerals (corundum, spinel, and sapphirine) in a highly calcic anorthosite from the Sittampundi Layered Complex, Tamil Nadu, India. Contrib. Mineral. Petrol. 2017, 172, 67. [CrossRef]

11. Gibson, G.M. Margarite in Kyanite- and Corundum-Bearing Anorthosite, Amphibolite, and Hornblendite from Central Fiordland, New Zealand. Contrib. Miner. Petrol. 1979, 68, 171-179. [CrossRef]

12. Pratt, G.H. Corundum and Its Occurrence and Distribution in the United States; US Government Printing Office: Washington, DC, USA, 1906.

13. McElhaney, M.S.; McSween, H.Y. Petrology of the Chunky Gal Mountain mafic-ultramafic complex, North Carolina. GSA Bull. 1983, 94, 855-874. [CrossRef]

14. Koptev-Dvornikov, V.S.; Kuznetsov, E.A. Borzovskoe Corundum Deposit: Petrological Study; State Technical Publishing House: Moscow, Russia, 1931; p. 320. (In Russian)

15. Claire, M.O. Corundum and emery on the Urals. Uralskiy Technik. 1918, 7, 1-17. (In Russian)

16. Kolesnik, N.Y. High-Temperature Metasomatism in Ultrabasic Massifs; Science Publishing House: Novosibirsk, Russia, 1976; p. 240. (In Russian)

17. Kolesnik, N.Y.; Korolyuk, V.N.; Lavrent'ev, Y.G. Spinels and ore minerals of the Borzovsk deposit of corundum plagioclasites. Notes Russian Mineral. Soc. 1974, 103, 373-378. (In Russian)

18. Nedosekova, I.L.; Vladykin, N.V.; Pribakin, S.V.; Bayanova, T.B. The structure of the IlmenogorskyVishnevogorsky Miaskite-Carbonatite Complex: Origin, ore-bearing. Sources of matter (Ural, Russia). Geol. Ore Depos. 2009, 51, 157-181. (In Russian) [CrossRef]

19. Rusin, A.I.; Krasnobaev, A.A.; Valizer, P.M. Geology of the Ilmen Mountains: situation and problems. In Geology and Mineralogy of the Ilmenogorsky Complex: Situation and Problems; IGZ UB RAS: Miass, Russia, 2006; pp. 3-19. (In Russian)

20. Krasnobaev, A.A.; Puzhakov, B.A.; Petrov, V.I.; Busharina, S.V. Zirconology of metamorphites of the KyshtymArakulian strata of the Sysert-Ilmenogorsky complex. Proc. Zavaritsky Inst. Geol. Geochem. (Trudy Instituta Geologii i Geokhimii im. Akademika A.N. Zavaritskogo) 2009, 156, 264-268. (In Russian)

21. Kramm, U.; Blaxland, A.B.; Kononova, V.A.; Grauert, B. Origin of the Ilmenogorsk-Vishnevogorsk nepheline syenites, Urals, USSR, and their time of emplacement during the history of the Ural fold belt: A Rb-Sr study. J. Geol. 1983, 91, 427-435. [CrossRef]

22. Kramm, U.; Chernyshev, I.V.; Grauert, S. Zircon typology and U-Pb systematics: A case study of zircons from nefeline syenite of the Il'meny Mountains, Ural. Petrology 1993, 1, 474-485.

23. Chernyshev, I.V.; Kononova, V.A.; Kramm, U. Isotope geochronology of alkaline rocks of the Urals in the light of zircon uranium-lead data. Geochemistry 1987, 3, 323-338.

24. Ivanov, K.S.; Erokhin, Y.V. About the Age and nature of the metamorphic complexes of the Ilmenogorsk zone of the Urals. Rep. Acad. Sci. 2015, 461, 312-315. 
25. Filina, M.I.; Sorokina, E.S.; Rassomakhin, M.A.; Kononkova, N.N.; Kostitsyn, Y.A.; Orlova, A.V. Genetic linkage of corundum plagioclazite-kyshtymite and miaskites of Ilmensky-Vishnevogorsky complex, Southern Urals, Russia: new data on Rb-Sr and Sm-Nd isotopic composition, geochemistry and mineralogy. Geochem. Int. 2019. (accepted).

26. Arslanova, K.A.; Golubchina, M.N.; Iskanderova, A.D. Geological Dictionary; Nedra Publishing House: Moscow, Russia, 1978; Volume 2, p. 456. (In Russian)

27. Jochum, K.P.; Weis, U.; Stoll, B.; Kuzmin, D.; Yang, Q.; Raczek, I.; Jacob, D.E.; Stracke, A.; Birbaum, K.; Frick, D.A.; et al. Determination of reference values for NIST SRM 610-617 glasses following ISO Guidelines. Geostand. Geoanal. Res. 2011, 35, 397-429. [CrossRef]

28. Jochum, K.P.; Scholz, D.; Stoll, B.; Weis, U.; Wilson, S.A.; Yang, Q.; Schwalb, A.; Börner, N.; Jacob, D.E.; Andreae, M.O. Accurate trace element analysis of speleothems and biogenic calcium carbonates by LA-ICP-MS. Chem. Geol. 2012, 318, 31-44. [CrossRef]

29. Jackson, S.E.; Pearson, N.J.; Griffin, W.L.; Belousova, E.A. The application of laser ablation-inductively coupled plasma-mass spectrometry to in situ U-Pb zircon geochronology. Chem. Geol. 2004, 211, 47-69. [CrossRef]

30. Kooijman, E.; Berndt, J.; Mezger, K. U-Pb dating of zircon by laser ablation ICP-MS: Recent improvements and new insights. Eur. J. Miner. 2012, 24, 5-21. [CrossRef]

31. Wiedenbeck, M.; Alle, P.; Corfu, F.; Griffin, W.L.; Meier, M.; Oberli, F.; von Quadt, A.; Roddick, J.C.; Spiegel, W. Three natural zircon standards for U-Th-Pb, Lu-Hf, trace-element and REE analyses. Geostand. Newsl. 1995, 19, 1-23. [CrossRef]

32. Ludwig, K.R. A User's Manual; Barkeley Geochonology Center: Berkeley, CA, USA, 2009; p. 100.

33. Platonov, A.N.; Taran, M.N.; Balitsky, V.S. The Nature of the Coloring of Gems; Nedra Publishing House: Moscow, Russia, 1984; p. 196. (In Russian)

34. Sorokina, E.S.; Koivula, J.I.; Muyal, J.; Karampelas, S. Multiphase fluid inclusions in blue sapphires from the Ilmen Mountains, southern Urals. Gems Gemol. 2016, 52, 209-211.

35. Peucat, J.J.; Ruffault, P.; Fritch, E.; Bouhnik-Le Coz, M.; Simonet, C.; Lasnier, B. Ga/Mg ratio as a new geochemical tool to differentiate magmatic from metamorphic blue sapphires. Lithos 2007, 98, 261-274. [CrossRef]

36. Sutherland, F.L.; Zaw, K.; Meffre, S.; Giuliani, G.; Fallick, A.E.; Graham, I.T.; Webb, G.B. Gem-corundum megacrysts from east Australian basalt fields: trace elements, oxygen isotopes and origins. Aust. J. Earth Sci. 2009, 56, 1003-1022. [CrossRef]

37. Zwaan, J.C.; Buter, E.; Merty-Kraus, R.; Kane, R.E. The origin of Montana's alluvial sapphires. Gems Gemol. 2015, 51, 370-391.

38. Uher, P.; Giuliani, G.; Szaka, L.L.S.; Fallick, A.; Strunga, V.; Vaculovic, T.; Ozdin, D.; Greganova, M. Sapphires related to alkali basalts from the Cerov'a Highlands, Western Carpathians (southern Slovakia): Composition and origin. Geologica Carpathica 2012, 63, 71-82. [CrossRef]

39. Palke, A.C.; Wong, J.; Verdel, C.; Avila, J.N. A common origin for Thai/Cambodian rubies and blue and violet sapphires from Yogo Gulch, Montana, U.S.A.? Am. Mineral. 2018, 103, 469-479. [CrossRef]

40. Giuliani, G.; Caumon, G.; Rakotosamizanany, S.; Ohnenstetter, D.; Rakototondrazafy, M. Classification chimique des corindons par analyse factorielle discriminante: application a la typologie des gisements de rubis et saphirs. Chapter mineralogy, physical properties and geochemistry. Revue Gemmol. 2014, 188, $14-22$.

41. Sun, S.S.; McDonough, W.F. Chemical and isotopic systematics of oceanic basalts: Implications for mantle composition and processes. Geol. Soc. London Spec. Publ. 1989, 42, 313-345. [CrossRef]

42. Fowler, A.; Prokoph, A.; Stenr, R.; Dupuis, C. Organization of oscillatory zoning in zircon: Analysis, scaling, geochemistry, and model of a zircon from Kipawa, Quebec, Canada. Geochim. Cosmochim. Acta. 2002, 66, 311-328. [CrossRef]

43. Belousova, E.A.; Griffin, W.L.; O’Reilly, S.Y.; Fisher, N.I. Igneous zircon: trace element compositon as an indicator of source rock type. Contrib. Mineral. Petrol. 2002, 143, 602-622. [CrossRef]

44. Watson, E.B.; Wark, D.A.; Thomas, J.B. Crystallization thermometers for zircon and rutile. Contrib. Mineral. Petrol. 2006, 151, 413-433. [CrossRef]

45. Nedosekova, I.L.; Belyatsky, B.V.; Belousova, E.A. Trace elements and Hf isotope composition as indicator of zircon genesis due to the evolution of alkaline-carbonatite magmatic system (Il'meny-Vishnevogorsky complex, Urals, Russia). Geol. Geophys. 2016, 57, 1135-1154. [CrossRef] 
46. Fersman, L.E. Pegmatites; Publishing House of the Academy of Sciences of the USSR: Moscow, Russia, 1940; p. 712. (In Russian)

47. Lodochnikov, V.N. Serpentines and Serpentinites Ilchirsk and Other Petrological Issues Associated with Them; United Scientific and Technical Publishing: Moscow, Russia, 1936; p. 817. (In Russian)

48. Korzhinskiy, D.S. Essay on metasomatic processes. In The Main Problems in the Theory of Magmatic Ore Deposits; Publishing House of the Academy of Sciences of the USSR: Moscow, Russia, 1953; pp. 332-450. (In Russian)

49. Eskova, E.M.; Zhabin, A.G.; Mukhitdinov, G.N. Mineralogy and Geochemistry of Rare Elements of the Vishnevogorsky Mountains; Science Publishing House: Moscow, Russia, 1964; p. 318. (In Russian)

50. Nedosekova, I.L. U-Pb age and Lu-Hf isotopic systems of zircons Ilmenogorsky-Vishnevogorsky alkaline-carbonatitic complex, South Ural. Lithosphere 2014, 5, 19-31. (In Russian)

51. Sutherland, F.L.; Abduriym, A. Geographic typing of gem corundum: a test case from Australia. J. Gemmol. 2009, 31, 203-210. [CrossRef]

52. Giuliani, G.; Fallick, A.E.; Garnier, V.; France-Lanord, C.; Ohnenstetter, D.; Schwarz, D. Oxygen isotope composition as a tracer for the origins of rubies and sapphires. Geology 2005, 33, 249-252. [CrossRef]

53. Vysotsky, S.V.; Nechaev, V.P.; Kissin, A.Y.; Yakovlenko, V.V.; Velivetskaya, T.A.; Sutherland, F.L.; Agoshkov, A.I. Oxygen isotopic composition as an indicator of ruby and sapphire origin: A review of Russian occurrences. Ore Geol. Rev. 2015, 68, 164-170. [CrossRef]

54. Sutherland, F.L.; Giuliani, G.; Fallick, A.E.; Garland, M.; Webb, G. Sapphire-ruby characteristics, West Pailin, Cambodia: Clues to their origin based on trace element and $\mathrm{O}$ isotope analysis. Aust. Gemmol. 2008, 23, 329-368.

55. Sutherland, F.L.; Schwarz, D.; Jobbins, E.A.; Coenraads, R.R.; Webb, G. Distinctive gem corundum suites from discrete basalt fields: a comparative study of Barrington, Australia, and west Pailin, Cambodia, gemfields. J. Gemmol. 1998, 26, 65-85. [CrossRef]

56. Saeseaw, S.; Sangsawong, S.; Vertriest, W.; Atikarnsakul, U. An In-Depth Study of Blue Sapphires from Pailin, Cambodia; Gemological Institute of America report: Carlsbad, CA, USA, 2017; p. 45.

57. Grimes, C.B.; John, B.E.; Kelemen, P.B.; Mazdab, F.K.; Wooden, J.L.; Cheadle, M.J.; Hanghoj, K.; Schwartz, J.J. Trace element chemistry of zircons from oceanic crust: A method for distinguishing detrital zircon provenance. Geology 2007, 35, 643-646. [CrossRef]

58. Grimes, C.B.; Wooden, J.L.; Cheadle, M.J.; John, B.E. “Fingerprinting” tectono-magmatic provenance using trace elements in igneous zircon. Contrib. Mineral. Petrol. 2015, 170, 46. [CrossRef]

59. Botcharnikov, R.E.; Almeev, R.R.; Koepke, J.; Holtz, F. Phase relations and liquid lines of descent in hydrous ferrobasalt-Implications for the Skaergaard Intrusion and Columbia River flood basalts. J. Petrol. 2008, 49, 1687-1727. [CrossRef]

60. Arndt, N. The formation of massif anorthosite: Petrology in reverse. Geosci. Front. 2013, 7, 875-889. [CrossRef]

61. Leet, J.K.; Williams, I.S.; Ellis, D.J. Pb, U and Th diffusion in natural zircon. Nature 1997, 390, 159-162.

62. Biondi, J.C. Neoproterozoic Cana Brava chrysotile deposit (Goiás, Brazil): Geology and geochemistry of chrysotile vein formation. Lithos 2014, 184, 132-154. [CrossRef]

63. Varlakov, A.S.; Kuznetsov, G.P.; Korablev, G.G. Hyperbasites of the Ilmenogorsky-Vishnevogorsky complex Complex (Southern Urals); Publishing House of the Institute of Mineralogy, Ural Branch RAS: Miass, Russia, 1998; p. 195. (In Russian)

64. Yakymchuk, C.; Kristoffer, S. Corundum formation by metasomatic reactions in Archean metapelite, SW Greenland: Exploration vectors for ruby deposits within high-grade greenstone belts. Geosci. Front. 2017, 9, 1-24. [CrossRef]

65. Hofmann, A.W. Mantle geochemistry: The message from oceanic volcanism. Nature 1997, 385, $219-229$. [CrossRef]

(C) 2019 by the authors. Licensee MDPI, Basel, Switzerland. This article is an open access article distributed under the terms and conditions of the Creative Commons Attribution (CC BY) license (http://creativecommons.org/licenses/by/4.0/). 